Portland State University

PDXScholar

Spring 2011

\title{
Macroinvertebrate Community Analysis on Lower Hood River Before and During the Removal of Powerdale Dam: A Baseline Study
}

Howard Jay Patterson

Portland State University

Follow this and additional works at: https://pdxscholar.library.pdx.edu/mem_gradprojects

Part of the Environmental Indicators and Impact Assessment Commons, Natural Resources

Management and Policy Commons, and the Water Resource Management Commons

Let us know how access to this document benefits you.

\section{Recommended Citation}

Patterson, Howard Jay, "Macroinvertebrate Community Analysis on Lower Hood River Before and During the Removal of Powerdale Dam: A Baseline Study" (2011). Master of Environmental Management Project Reports. 19.

https://pdxscholar.library.pdx.edu/mem_gradprojects/19

https://doi.org/10.15760/mem.39

This Project is brought to you for free and open access. It has been accepted for inclusion in Master of Environmental Management Project Reports by an authorized administrator of PDXScholar. Please contact us if we can make this document more accessible: pdxscholar@pdx.edu. 


\title{
Macroinvertebrate Community Analysis on lower Hood River Before and During the Removal of Powerdale Dam: \\ A Baseline Study
}

\author{
by Howard Jay Patterson
}

\author{
Portland State University \\ Department of Environmental Science and Management
}

prepared in partnership with Hood River Watershed Group
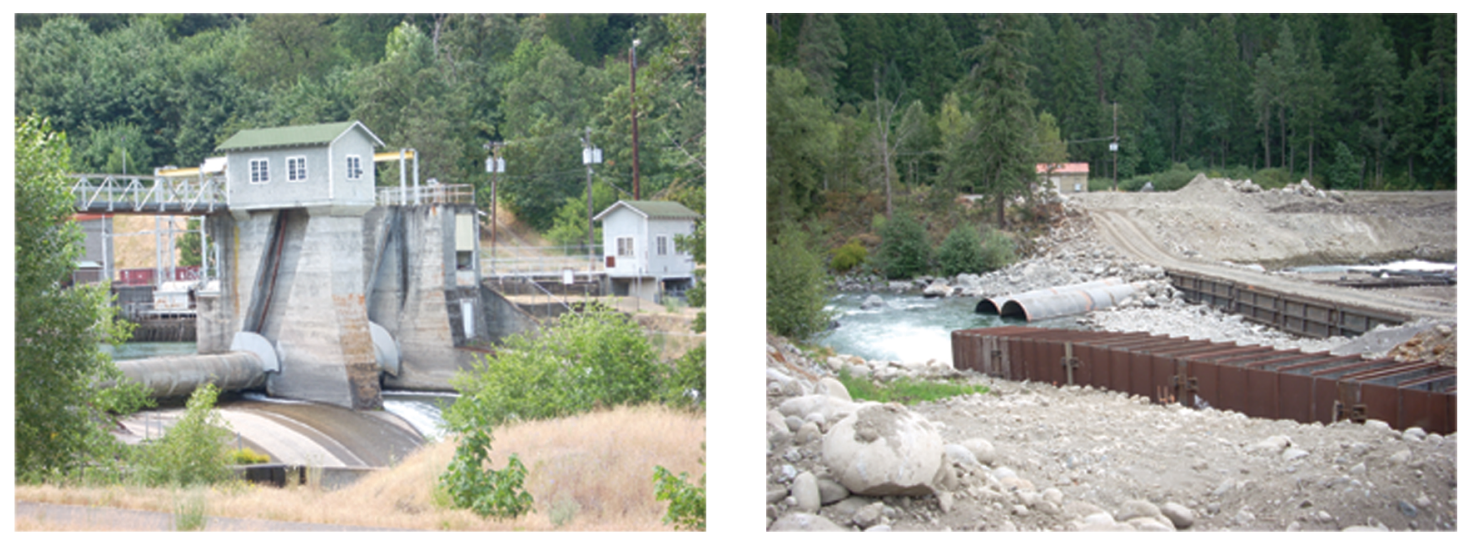

A Master's Project submitted to the Department of Environmental Sciences and Management in fulfillment of the requirements for the degree of Master's of Environmental Management in the Graduate College of Portland State University 


\begin{abstract}
Powerdale Dam was an 87-year-old hydroelectric complex on lower Hood River in northern Oregon which was decommissioned in 2010. Macroinvertebrate samples were collected in 2009, before the removal process began, and in 2010, near the end of the demolition project, at one site upstream and three sites downstream of the dam. Macroinvertebrate communities were analyzed using both multi-metric (Benthic Index of Biotic Integrity [B-IBI]) and multivariate (Predictive Assessment Tool for Oregon [PREDATOR]) approaches, as well as EPT and Functional Feeding Group (FFG) analysis. All analytical approaches indicated declines in habitat quality in 2010 relative to 2009, and showed increasing impairment in the downstream sites in 2010, with sediment implicated as an impairment factor. Pollutants such as pesticides released from the impoundment might also contribute to downstream disturbance levels. The upstream, control site showed habitat quality declines in 2010 relative to 2009 , indicating a possible upstream source of impairment. The demolition project did not physically impact upstream areas, and tributary turbidity does not appear to have been elevated relative to other years; however, the Hilsenhoff Biotic Index indicates an increase in upstream nutrient pollution in 2010 relative to 2009 . Future research will be able to establish rate and extent of post-removal habitat recovery relative to these baseline data.
\end{abstract}

\title{
Introduction
}

Dam removal is a form of river restoration whose use is currently accelerating in frequency, as more $20^{\text {th }}$ century dams reach the end of their economically profitable and physically sustainable lives (Poff \& Hart 2002). Studies of the ecological effects of dam removal have not been extensive, due both to the relative newness of this restoration technique and to the general scarcity of funding for scientific study; the majority of dam removal studies have concentrated on sediment and hydrology (Roni et al. 2008).

Removing dams from river systems has obvious benefits to fish ecology and productivity, in the form of improved fish passage and access to upstream habitats, particularly in the case of anadromous fish, whose abundance has declined precipitously in the last century with lack of access to indigenous spawning grounds. (Roni et al. 2008, Santucci et al. 2005, Hart et al. 2002). The biotic integrity of impoundment areas appears to improve dramatically after removal as well (Catalano \& Bozek 2007). Northwest salmonids have been listed as endangered, and reopening spawning grounds in the upper Hood River basin by removing Powerdale Dam is expected to improve salmonid abundance in the Columbia Basin (Meridian Environmental, 2003). The Confederated Tribes of the Warm Springs Reservation have strongly supported the removal of Powerdale because the Treaty of 1855 insures their fishing rights throughout the basin, including regions far upstream that have been effectively excluded from salmonid reproduction by the construction of Powerdale Dam. 
Dam removal can also have negative habitat effects. Downstream habitats can change significantly with inundation by formerly impounded sediment, and the degree of damage, the extent to which those habitats recover, and the time necessary for that recovery vary widely according to specific local conditions of river, dam, and climate (Poff \& Hart 2002, Doyle et al. 2005, Ahearn \& Dahlgren 2005). In cases where pollutants such as pesticides or heavy metals have accumulated in the impounded sediments, removal can sometimes allow contamination of downstream habitats with those pollutants, whose persistence and toxicity in the environment, again, will vary with local conditions (Shuman 1995, Stanley \& Doyle 2003, Poff \& Hart 2002).

Analysis of aquatic macroinvertebrate communities has begun in the past several decades to emerge as a robust technique for evaluating the health of streams, lakes, wetlands, and other freshwater ecosystems. Beginning in the early $20^{\text {th }}$ century with the qualitative study of key indicator species to indicate pollution levels, and with the addition of quantitative sampling and statistical techniques in the last several decades, a spectrum of macroinvertebrate biomonitoring approaches are currently in use (Rosenberg et al. 2008). Macroinvertebrates are animals without backbones, large enough to see - generally considered to be about $0.5 \mathrm{~mm}(500 \mu)$ in length: while the term includes mollusks, some crustaceans, and worms such as nematodes and annelids, the great majority of taxa under consideration are insects. A number of factors contribute to the usefulness of macroinvertebrate studies for biomonitoring of aquatic habitats:

- Macroinvertebrates are nearly ubiquitous, found in some form in virtually every body of fresh water.

- Most macroinvertebrate taxa are relatively long lived, so that their response to intermittent phenomena persists even after a momentary condition that might be missed by conventional chemical testing has dissipated.

- The ranges of most individual macroinvertebrates are small, so their physiological responses are likely to be tied to very local conditions.

- There are a very large number of aquatic macroinvertebrate taxa, whose sensitivities to water quality parameters vary across a wide spectrum. Thus, the presence, absence and proportions of particular taxa can reveal many details about the quality of a body of water.

- Collection, indentification, and analysis of macroinvertebrates can be less expensive than laboratory chemical testing.

- Macroinvertebrates serve many functional roles in the aquatic foodweb, ranging from shredders of detritus to grazers of algae to filter-feeders to predators. All these functional guilds are, in turn, the primary food source for many fish species, in particular the anadromous salmon species so important to Pacific Northwest ecologies, economies, and cultures. 
- Macroinvertebrate population study is thus not only convenient, but is a real and accurate reflection of the ecological make-up of a stream, river, or wetland (Rosenberg \& Resh 1993, Wallace \& Webster 1996).

A number of approaches have been developed to analyze macroinvertebrate data. Multimetric scoring systems analyze a range of taxonomic data and assign a numerical score for each metric; then those scores are added for a site score. Multivariate analysis uses an extensive regional database to statistically determine the macroinvertebrate taxa expected in streams with particular habitat features, and to compare those expected taxa with actual observed taxa collected from that site. Oregon Department of Environmental Quality has found that using both types of analysis in combination probably gives the best assessment of environmental stressors (Hafele 2003). This study uses the multi-metric and multivariate analytical techniques currently ascendant in Oregon: the Benthic Index of Biological Integrity (B-IBI), described by the Oregon Plan for Salmon and Watersheds (Oregon Plan 1999); and the Predictive Assessment Tool for Oregon (PREDATOR), developed by the Oregon Department of Environmental Quality (Hubler 2008). Other forms of analysis, including EPT (Ephemeroptera/Plecoptera/Trichoptera) and Functional Feeding Group (FFG) ecological surrogates, are also explored.

The author collected macroinvertebrate samples after the removal of Marmot Dam on the Sandy and Little Sandy Rivers in Western Oregon in 2008, only to find that those postremoval data are of limited usefulness for examining the ecological effects of that dam removal project; no baseline samples were collected or analyzed before the dam was removed, so that there is no basis by which to compare the pre- and post-removal health status of the river. In an attempt to avoid another such missed opportunity to evaluate the effects of dam removal, this report establishes macroinvertebrate community baselines for lower Hood River before the removal of Powerdale Dam and during the removal process. (The intent had been to collect data immediately after the Dam's removal, but the dam had not yet been breached by the sampling period.) With this baseline data, future research will be able to examine the habitat impacts of removal, and to determine rates and extent of recovery in comparison to this pre-removal information. This information will be crucial to Hood River Watershed Group, and to any other organizations concerned with the health of the river, in determining the effect of the dam's removal on the long-term recovery and restoration of the lower river. Further, since aquatic organisms, in particular anadromous fish species, must pass through the bottleneck of the lower channel to reach upstream areas, the habitat status of the lower river is critical to the ecological health of the entire watershed. 


\section{Study Site}

Hood River basin in north central Oregon drains the eastern slopes of Mt. Hood, and empties into the Columbia River at the town of Hood River (Figure 1). The valley is one of the primary orchard and agricultural areas in the state: the county leads the nation in pear production, with over 11,000 acres devoted to that fruit, as well as over 3000 acres of other fruit production (USDA 2009). Pesticides and fertilizers used in the Valley have been found to impact the river and its habitats. ODEQ has found an annual decline in insect populations in the spring, weakly correlating with application of the triazine herbicide Simazine, followed by a summer population rebound (Hubler and Borisenko 2008). The organophosphate pesticide Chlorpyrifos has been found in concentrations exceeding water quality standards in surface waters of the Hood River basin (ODEQ 2003). ODEQ has noted high levels of total phosphates, biochemical oxygen demand, and total solids during summer low flow periods (ODEQ 1995). Water Quality Index averaged fair, with a decrease in quality in the 2008 averages relative to the previous decade (ODEQ 2008).

Powerdale Dam (also known as Copper Dam) was built in 1923 to generate electricity for the Hood River Valley, with a generating capacity of six megawatts. The dam's owner, PacifiCorp, agreed in 2003 to decommission it rather than make the major refurbishment and safety investments necessary for a new FERC license (Federal Energy Regulatory Commission). A large group of stakeholders worked cooperatively on the decommissioning agreement, including The Confederated Tribes of the Warm Springs Reservation, American Rivers, Hood River Watershed Group, and state and federal regulatory agencies including National Marine Fisheries Service, U.S. Fish and Wildlife Service, Oregon Department of Environmental Quality, Oregon Department of Fish and Wildlife, and Oregon Water Resources Department (HRSWCD 2010).

The dam complex (Figure 2) consisted of a 10' high, 206' long concrete diversion dam (at river mile 4.8); an 80' x 60' concrete intake structure: a reservoir with a storage capacity of 5 acre-feet; a 16,000' water conveyance system including a concrete canal, a large steel flume pipe carrying water three miles downstream, a settling pond, and surge tank; a concrete Powerhouse (at river mile 1.5) with a $6 \mathrm{MW}$ turbine-generator unit; a 15, rock-lined tailrace; downstream fish passage by way of a system of traveling belt screens in front of the intake structure and downstream release; and a small pool-and-weir fish trap for upstream fish passage. All fish attempting to swim upriver after 1992 were captured by the fish trap and diverted to the Powerdale Fish Facility, where adult salmon and steelhead were counted and biosampled daily by Oregon Dept of Fish and Wildlife researchers. All adult salmon and wild steelhead were released above Powerdale Dam; a proportion of hatchery steelhead were not allowed to pass over Powerdale and were relocated downstream (Meridian Environmental 2003, FERC 2005.) 
Figure 1. Hood River Sampling Sites, 2009-2010

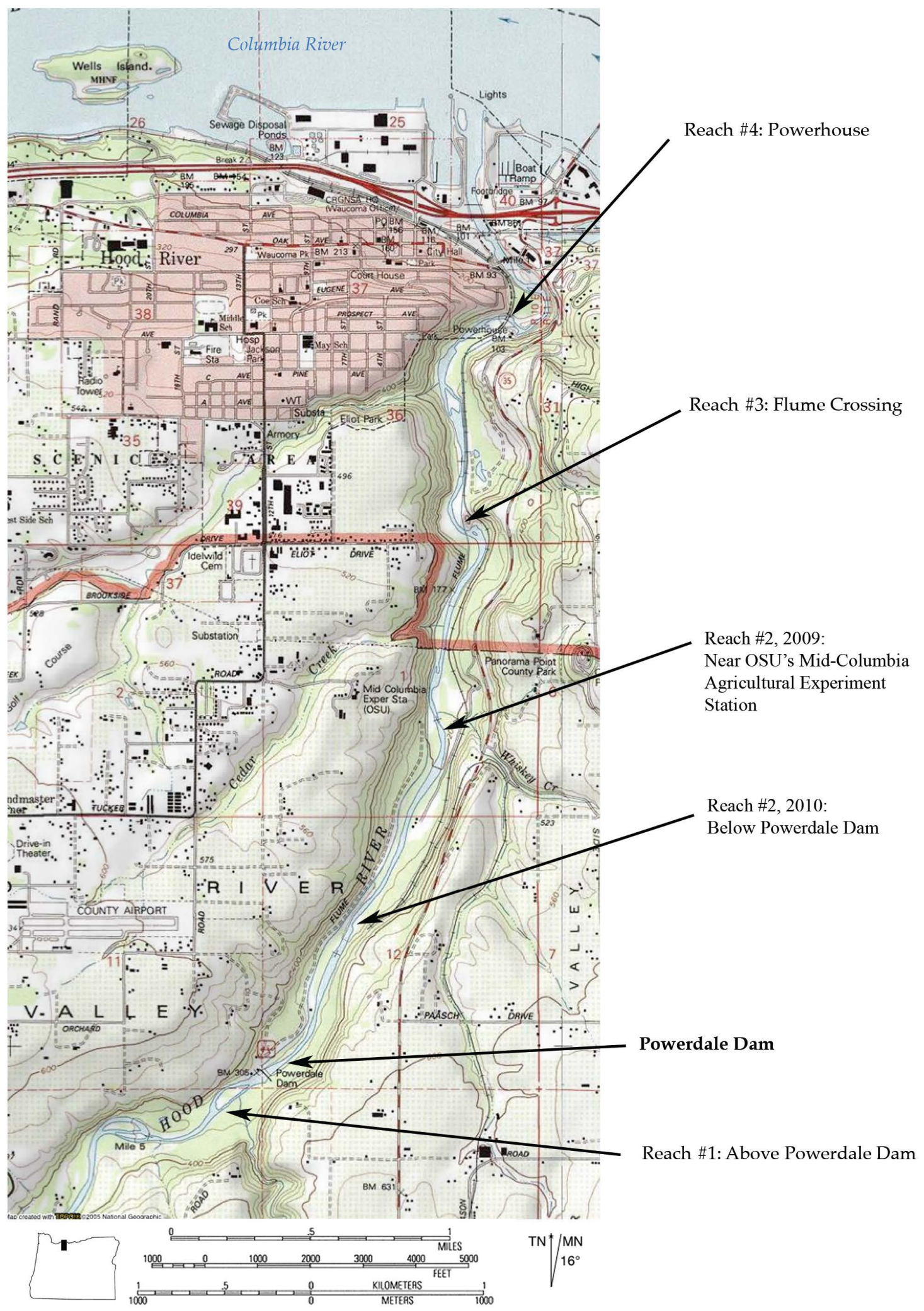




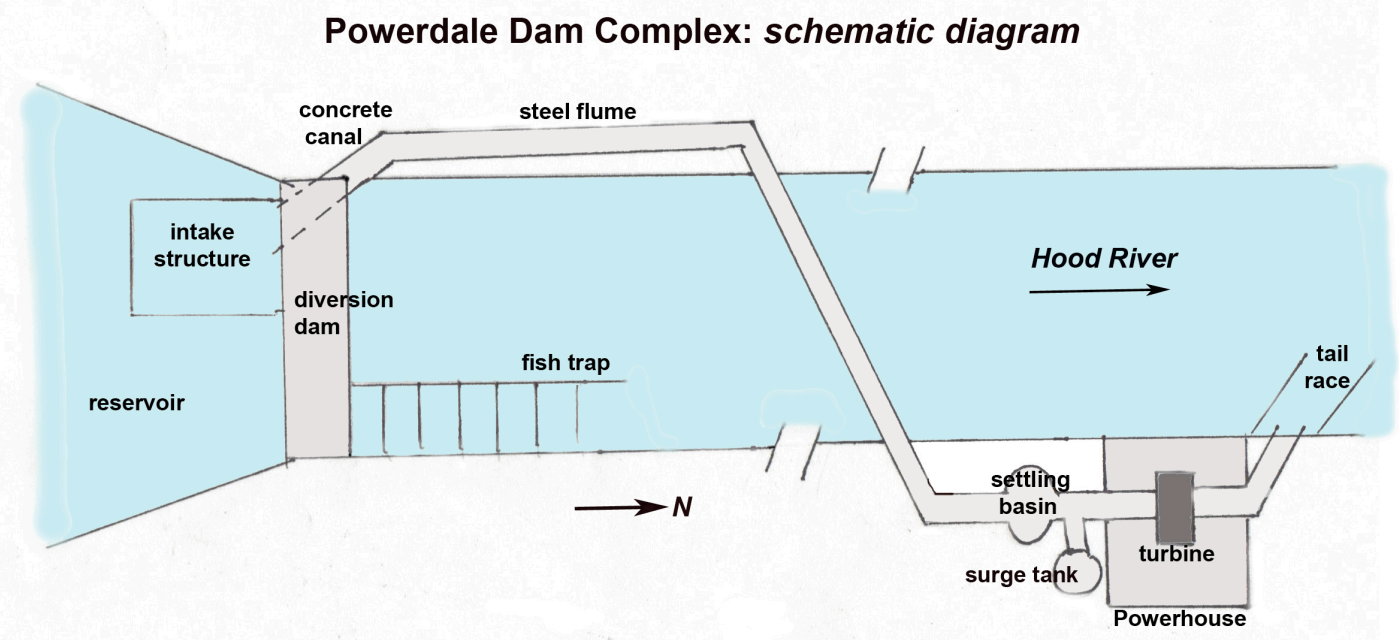

Figure 2. A schematic representation of the major elements in the Powerdale Dam Complex. Diagram not to scale.

Flooding in November of 2006 damaged the Powerhouse and flume structure, and filled much of the intake structure and tailrace with sediment. Rather than repair the structure and resume electrical service, PacifiCorp stabilized the damaged structures and waited for the scheduled 2010 decommission (PacifiCorp 2007). The deconstruction process began in April 2010, with the disassembly of the surge tank and tower at the Powerhouse site, and the demolition of much of the flume system. In July, tow steel and earth coffer dams were constructed a few meters upstream and downstream of the concrete dam structure, to allow its demolition in a dry environment; downstream fish passage was routed around the structure, and the fish ladder was extended to permit upstream fish passage. The concrete dam and its accompanying structures were demolished in August, channel reconstruction took place through September, and on September 23, 2010, the coffer dams were breached to allow Hood River to flow free of artificial structures for the first time in 87 years. Riparian regrading, restoration and replanting continued through October (HRSWCD 2010).

Four sampling sites were selected according to relationship to the dam (three below, one above, see Figure 1) and to the availability of wadeable, riffle habitats. Much of lower Hood River is deeply channelized, and the current and depth are inappropriate both for safe sampling procedures and for the analytical usefulness of the types of organisms resident in that type of habitat. The most sophisticated analytical techniques currently in use are based on organisms found in fast-flowing riffle habitats, which are generally the richest areas taxonomically, so that finding riffle sites was of paramount importance. In order to minimize variability from life cycle changes that would inevitably arise from sampling at different times of the year, all samples were collected in a three day period at the end of August and beginning of September (31 August - 2 September 2009, 30 August - 1 September 2010.) Each sample collection period began with Reach 4 the first day, continued with Reaches 3 and 2 on the second, and finished with Reach 1 on the third day of sampling. Descriptions of sites and access routes are included to facilitate future research. 

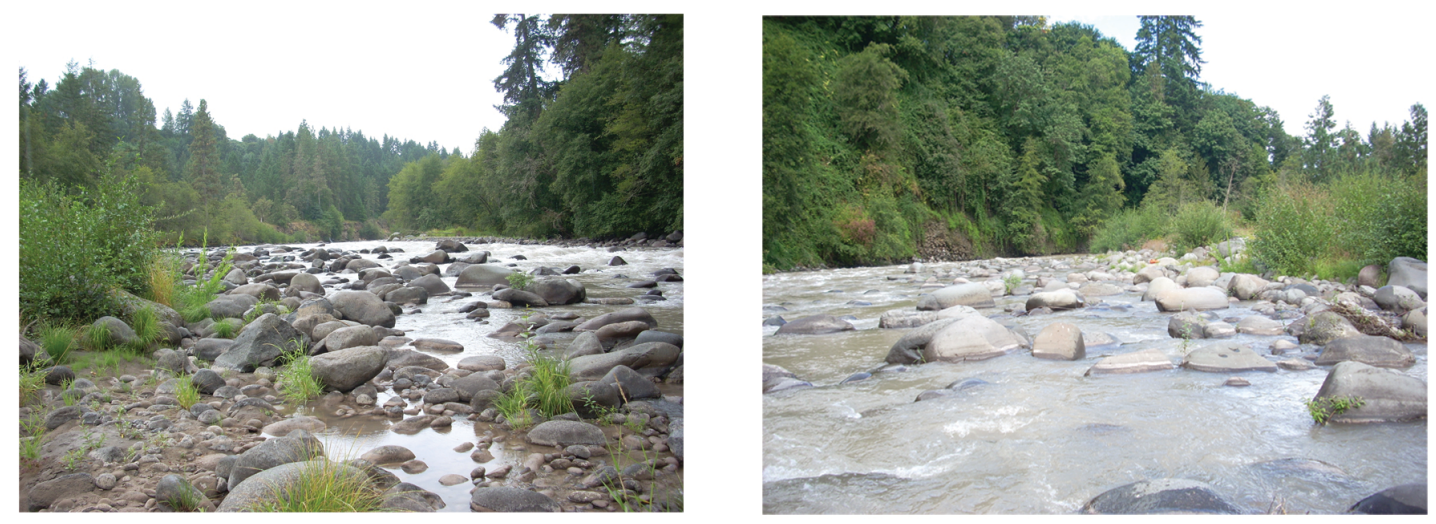

Reach 1 - Above Powerdale. View looking upstream, South (left) downstream, North (right).

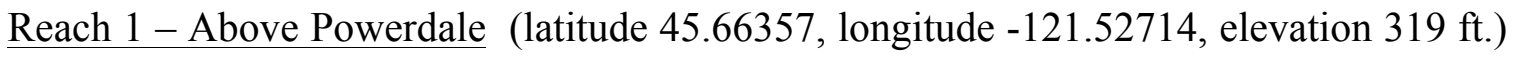
is an area 400-500 meters upstream of the dam, on the east bank of the river. It is accessed from the east side of the Dam site (having come down by way of the Fish Trap road, since the Dam is no longer there to use as a bridge from the west side), hiking south through the woods, crossing Neal Creek, and then crossing a large wooded island to the Hood River mainstem. Eight samples were collected along the river's east bank, progressing upstream. This was intended as a control site, to compare to sites downstream of the Dam.
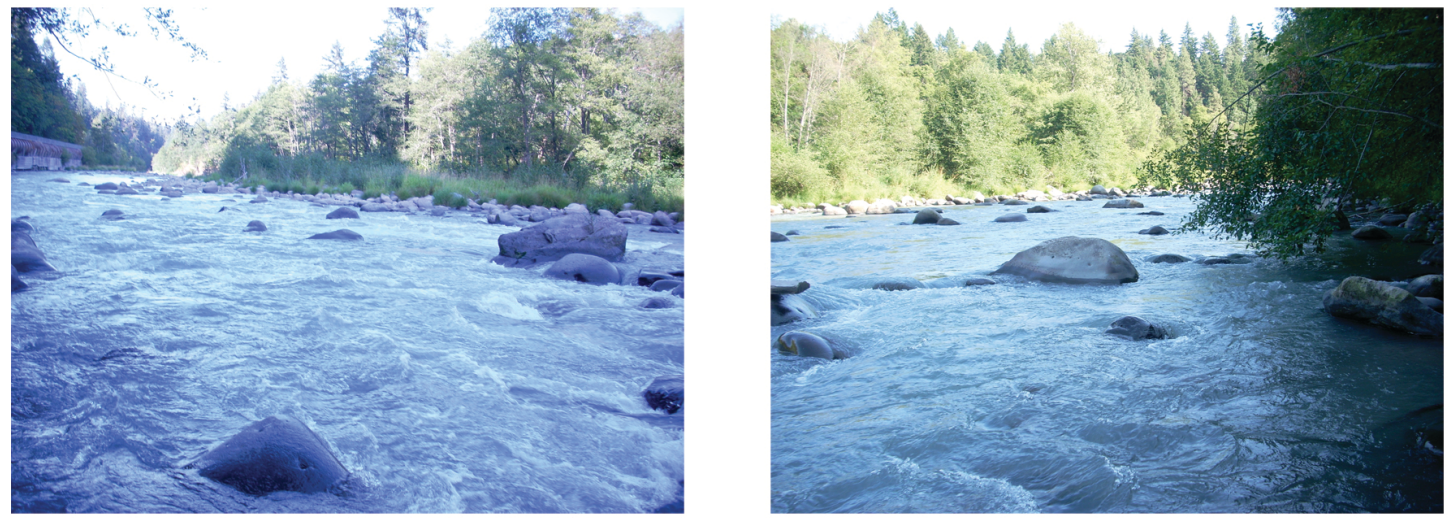

Reach 2 (2009) - Near OSU Experiment Station. View looking downstream/North (left), and upstream/South (right).

Reach 2 - Near OSU Experiment Station (latitude 45.68368, longitude -121.51065, elevation $185 \mathrm{ft}$.) is on the west bank of Hood River, roughly opposite the OSU MidColumbia Agricultural Experiment Station. The gorge is too steep for access from the Station: the site was reached in 2009 by way of a dirt road through the woods leading 
north from Powerdale Dam, which gradually dwindled to a path, concluding with some vigorous bushwhacking and scrambling. Eight samples were taken along the west bank, proceeding upstream. The sample site itself was the deepest and fastest flowing of all the reaches sampled.
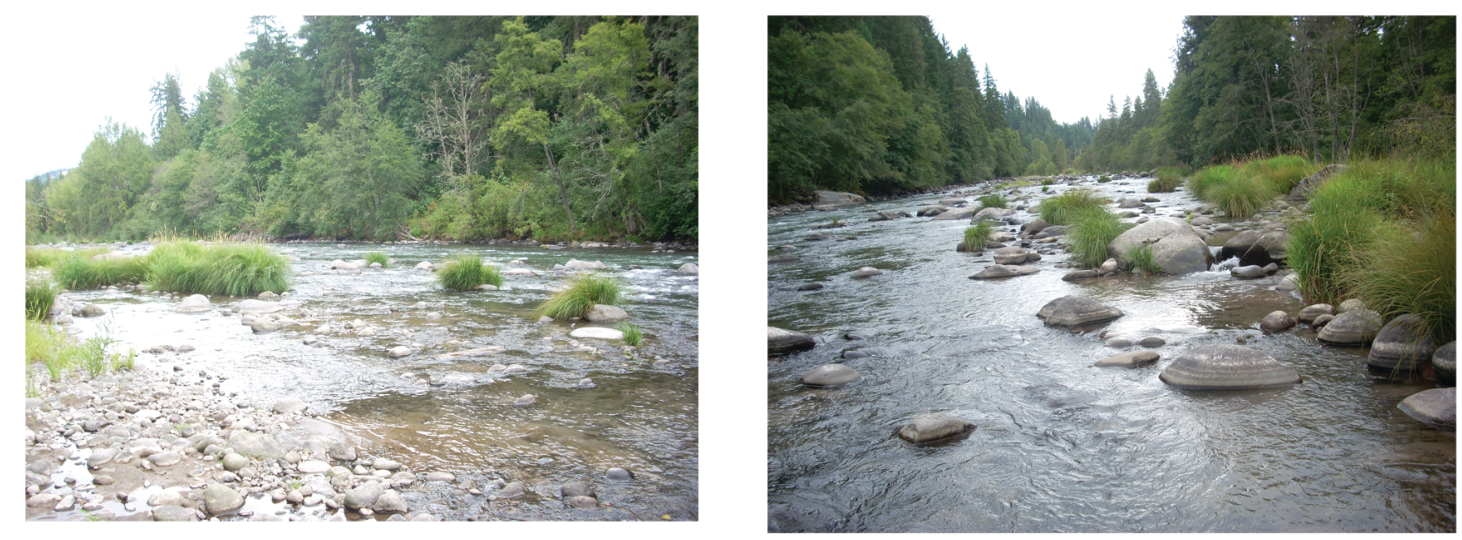

Reach 2 (2010) - Below Powerdale. View of reach looking downstream/North (left), and upstream/South (right).

In 2010, that dirt road had become part of the Powerdale Dam demolition project, much larger and built up to industrial capacity, with heavy road equipment hurtling at high speed and crews that discouraged pedestrian travel. Access to the original sampling site being essentially impossible, a new site was found by climbing down to the riverbank and following it northward as far as possible: this site, Reach 2 - Below Powerdale (latitude 45.67224, longitude -121.51777 , elevation $269 \mathrm{ft}$.), is also on the west bank, along the eastern side of a sandbar seperated from the bank by a narrow side channel. Sampling began upstream (south) of the side channel's confluence with the mainstem, continued up the eastern bank of the sandbar, and concluded with a sample in the entrance of the side channel. The sample site is a shallower riffle habitat than its 2009 counterpart, and lies approximately $2 \mathrm{~km}$ south of its predecessor. 

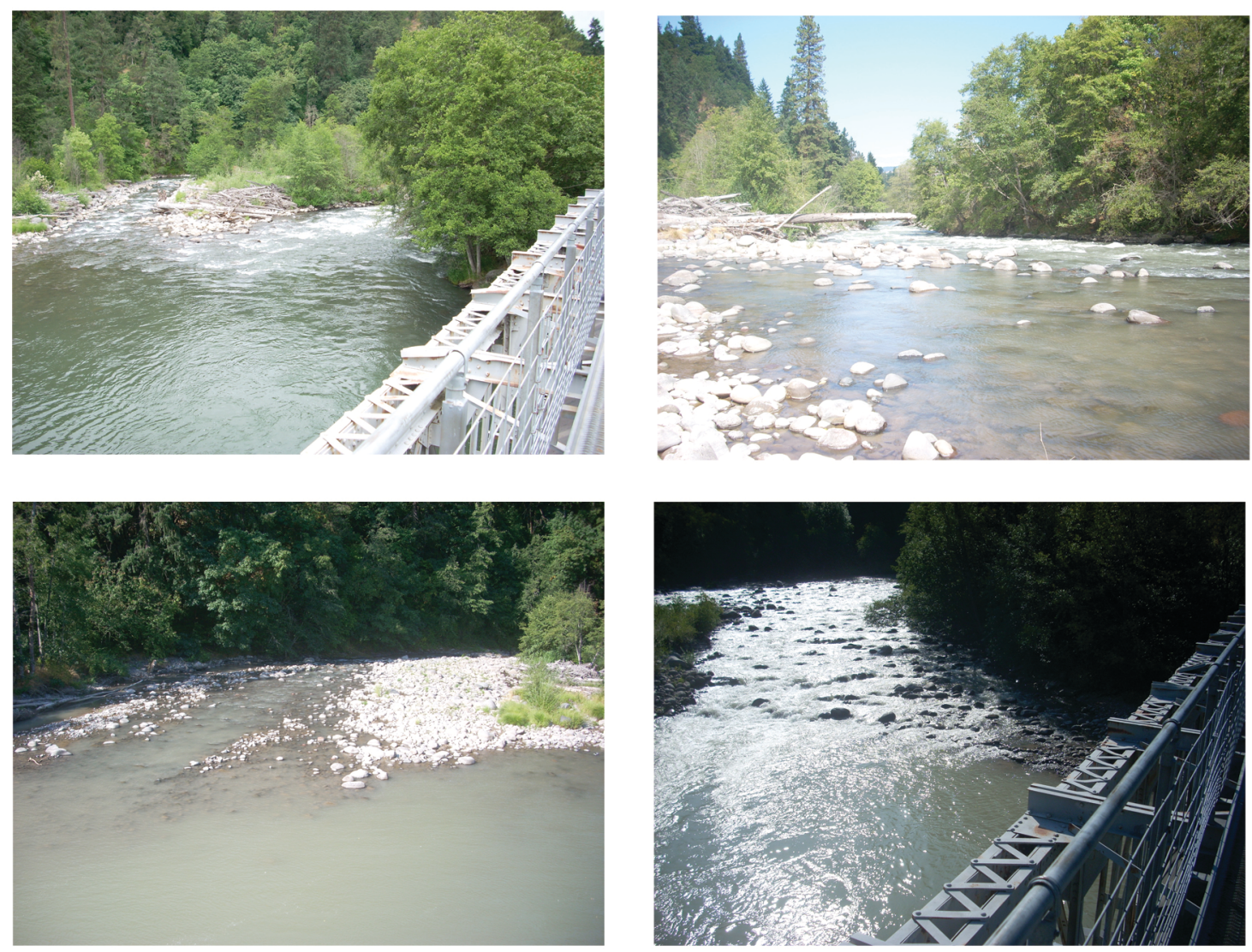

Reach 3 - Flume Crossing. View downstream/North from Flume bridge (upper left); downstream/North from midstream (upper right); West from midstream (lower left); and upstream/South from Flume bridge (lower right).

Reach 3 - Flume Crossing (latitude 45.69388, longitude -121.50913, elevation $132 \mathrm{ft}$.) is an area where the steel Flume crosses the river, and where the river itself opens up into a wide bend with a number of side channels. It is accessed by walking the dirt road south from the Powerhouse on the east bank, or by driving the dirt road from Hwy 35, and then crossing the river by way of the Flume bridge itself, then descending via a caged steel ladder. Sampling began on the west bank downstream of the Flume, proceeded across the large side channel, and concluded with two samples on the west bank upstream of the Flume. 

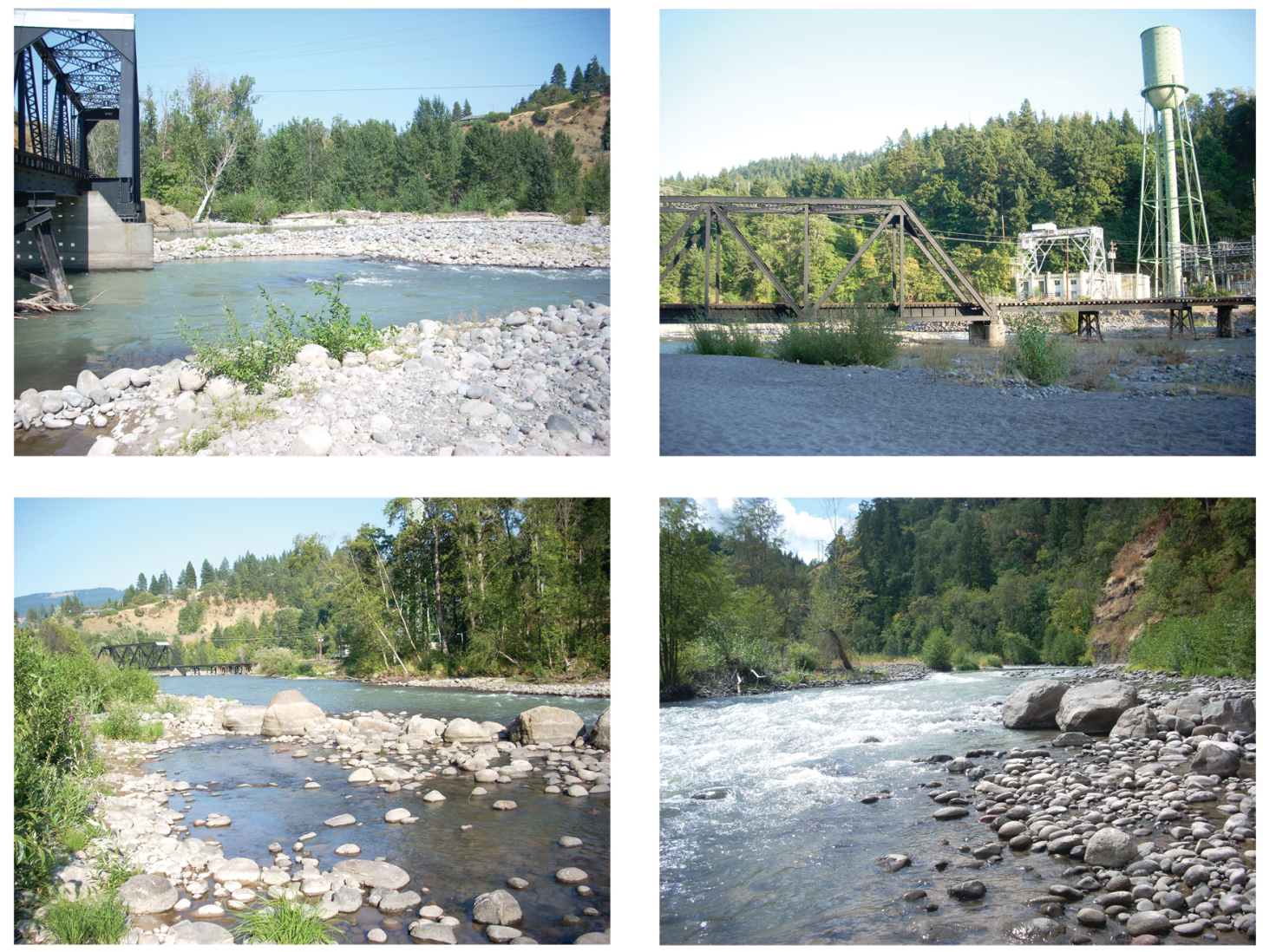

Reach 4 - Powerhouse. View downstream/North from East bank, downstream of railroad bridge (upper left); view of Powerhouse, surge tank tower, and RR bridge from West bank (upper right); view downstream/North from West bank upstream of RR bridge (lower left); and view upstream/South from West bank.

Reach 4 - Powerhouse (latitude 45.70416, longitude -121.50651, elevation $105 \mathrm{ft}$.$) is an$ area opposite the PacificCorp Powerhouse, just off Highway 35, on both sides of the river. On the east bank, two samples were collected downstream of the railroad bridge and two upstream; then the bridge was crossed, and four samples were taken on the west bank upstream of the bridge.

\section{Methods}

The collection and analysis techniques used in this study were developed for use in perennial, wadeable streams. Hood River is certainly perennial, but its wadeability in the lower reaches, even at summer low flow, is debatable. Neither is its flow slow enough nor its depth great enough to permit standard boat-based grab-sampling protocols (Flotemersch et al. 2001.) The US Environmental Protection Agency's Environmental Monitoring \& Assessment Program (EMAP) described a protocol for sampling the wadeable margin of non-wadeable streams with kick-nets; this method samples from 
regularly spaced transects, irrespective of habitat type (USEPA 2003). However, Shannon Hubler of ODEQ, who developed the PREDATOR statistical model, suggested that sampling the wadeable margins of non-wadeable rivers in Oregon by instead targeting riffle habitats, using ODEQ sampling protocols, should yield data that would be appropriate for PREDATOR analysis (S. Hubler, personal communication, 2009).

Samples were collected according to ODEQ standard protocols, using a $500 \mu$ Wildco dipnet. Eight $1 \mathrm{ft}^{2}$ sample areas were randomly selected using the 9-cell visual grid technique, beginning at the downstream end of the sample reach and collecting one sample from each riffle/fast-moving habitat (ODEQ 2009, Hayslip 2007). For each sample, the dipnet was placed against the substrate, all stones $>3 \mathrm{~cm}$ in a $1 \mathrm{ft}^{2}$ area upstream of the sample net were hand-scoured, then scoured with a Wildco periphyton brush, then removed from the sample area; then the substrate was disrupted with hand movements to a depth of $10 \mathrm{~cm}$ for 60 seconds. The eight samples were then composited into a single sample and preserved in $80 \%$ ethanol.

Each sample was subsampled using a Caton subsampling tray. The sample was distributed uniformly across a $500 \mu$ screen divided into thirty $6 \times 6 \mathrm{~cm}$ cells, cells were selected randomly (using an ODEQ random number card), and all organisms within each selected cell were counted, using a Jenco stereo microscope. Additional cells were selected and counted until at least three cells had been selected and at least 500 organisms had been counted.

Although the author had originally intended to perform all taxonomic identification himself, it became evident that his skills are not yet sufficiently sophisticated for the level of speed and accuracy necessary for high-resolution analysis. Therefore, in the interests of producing the most accurate information possible in a timely manner, the author commissioned Dr. Michael Cole of ABR, Inc. to perform all taxonomic identification.

After identification, datasets, which had been physically subsampled to between 505 and 652 organisms using the Caton method described above, were subsampled again electronically, using ODEQ software obtained from S. Hubler. Number of organisms per sample was reduced to $n=500$ for B-IBI analysis, and again to $n=300$ for PREDATOR analysis, as is required by each respective analytical protocol.

\section{Results and Analysis}

Biotic data for all site samples can be found in Appendix A, page 38.

\section{EPT}

Macroinvertebrate habitat analysis is a relatively new discipline, and a number of mathematical techniques developed in other ecological studies have been applied, with 
varying degrees of success and applicability. A comparison of a range of standard ecological analysis tools, including diversity indices, similarity indices, and Hilsenhoff biotic indices, found the most descriptive technique for examining changes in aquatic quality to be EPT, the percentage of sampled organisms belonging to three insect orders: Ephemeroptera (mayflies), Plectoptera (stoneflies), and Trichoptera (caddisflies) (Lydy et al 2000). Not all species in these orders are highly sensitive to environmental disturbance: some in fact are quite tolerant, including some species found in large numbers in the present samples. As a result, EPT is not a finely honed indicator of ecological disturbance, but it does reflect habitat conditions, is relatively easy to calculate, and has been utilized in many studies as a biomonitoring technique.

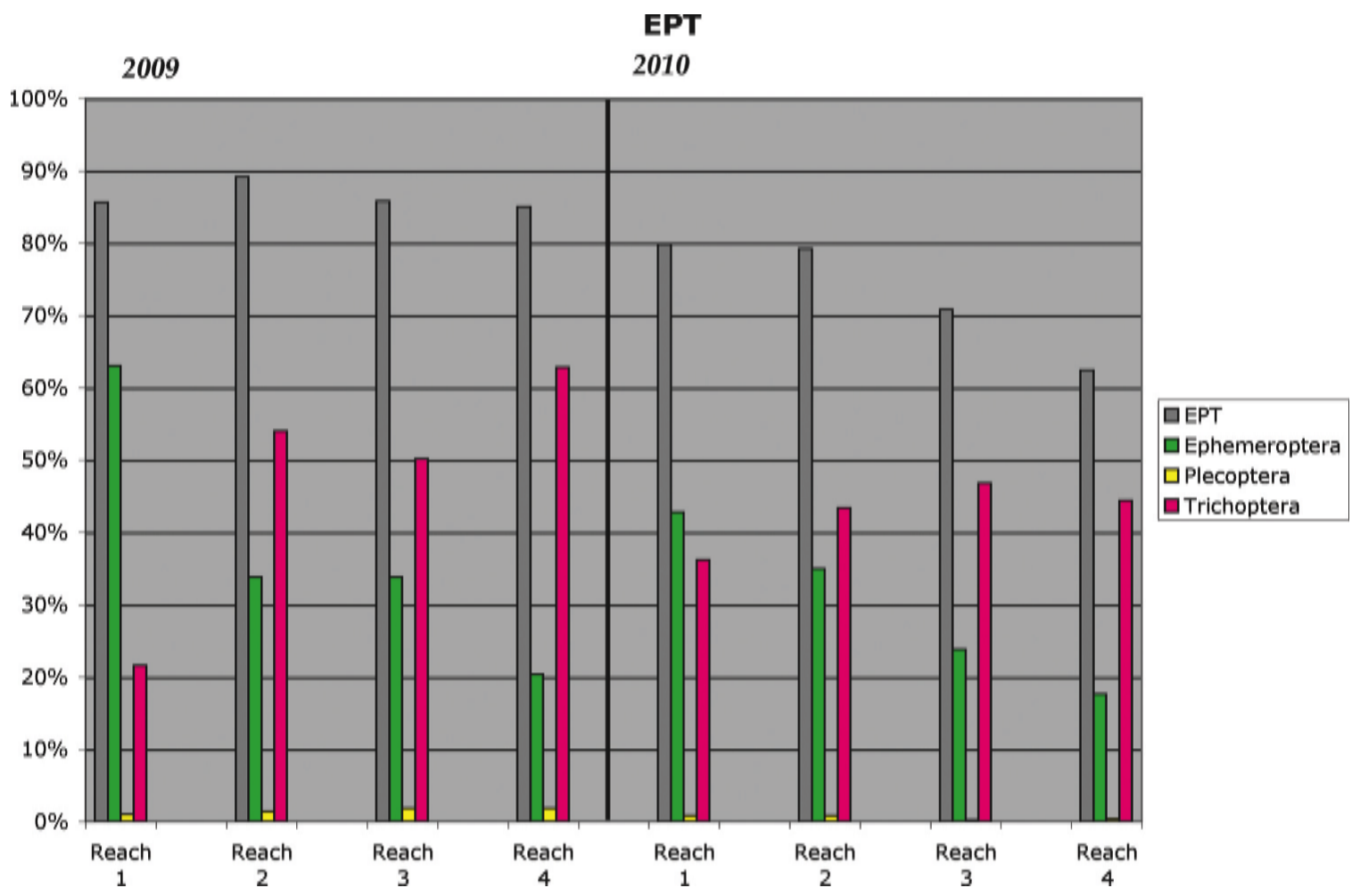

Figure 3. Percentages of each composited and subsampled reach sample $(n=500)$ belonging to the three EPT orders (grey), to Ephemeropthera alone (green), to Plecoptera (yellow), and to Trichoptera (red) for 2009 and 2010.

In 2009, before the dam removal process began, the percentage of total EPT (Figure 3) was, for an impacted system, surprisingly high throughout the study area, remaining consistently between 85 and 90\%. Examining the percentages of individual orders reveals a decline in Ephemeroptera (mayflies) progressing downstream, which is balanced by a similar increase in Trichoptera (caddisflies). This effect is due to the influence of two highly abundant taxa: the small minnow mayfly Baetis tricaudatus, and the spotted sedge caddisfly Hydropsyche. While B. tricaudatus is the more rugged of the two common species of Baetis in Oregon, generally found in less pristine waters than its relative $B$. bicaudatus (largely because its optimal temperature range is over $3^{\circ} \mathrm{C}$ higher), 
Hydropsyche is in fact one of the small number of organisms coded by the Oregon DEQ as "tolerant" of disturbance, and can be assumed to be more disturbance-tolerant than Baetis. The progressive replacement of Baetis by Hydropsyche could thus indicate a progressive increase in disturbance factors moving downstream, which could include increased sedimentation, pesticide or nutrient concentrations, and/or the influence of tributary streams. It could, on the other hand, simply reflect the typical increase of importance of collector-filterers and decrease of collector-gatherers progressing downstream, as predicted by the River Continuum Concept (Vannote et al. 1980) [see Functional Feeding Groups, p. 25 below].

In 2010, during the dam removal process, all EPT percentages were significantly lower than in 2009 (Figure 3), starting below $80 \%$ and declining downstream to nearly $60 \%$. This could indicate a significant effect of the dam removal process on downstream habitat health. A similar pattern to that of 2009 can be seen in the changing proportions of Baetis and Hydropsyche, but far less pronounced, with the upstream percentages much more nearly equal, and the percentages of both orders falling off by Reach \#4, the Powerhouse, perhaps indicating an increasing disturbance level.

\section{Multi-metric}

The use of the presence or absence of specific organisms as a way to evaluate the health of aquatic systems has a long history, dating back to Germany in the early $20^{\text {th }}$ century (Rosenberg et al. 2008). The complexity of natural systems is such that a single attribute is seldom sufficient to fully reflect habitat condition. Systems that address this limitation by measuring a number of different attributes simultaneously are known as multi-metric systems. Since the development of J. R. Karr's Index of Biotic Integrity based on fish species (Karr 1981), many regional approaches to multi-metric evaluation of aquatic habitat have been developed, using a range of different taxa (including fish, diatoms, and macroinvertebrates) and a wide assortment of ecological criteria.

An Index of Biotic Integrity generally consists of a number of characteristics or "metrics" related to the taxa under investigation, for each of which the dataset is evaluated and given a score - generally 5 for a condition resembling that expected for a site with little or no human contact, 3 for a moderately degraded site, and 1 for severely degraded status - and those scores added up to yield a total score for the site. Thus, in a system with 5 metrics, the total score could range between 5 for the worst possible condition and 25 for the most pristine stream.

Fore and others tested 30 possible attributes of macroinvertebrates in Oregon streams, found 10 to be reliable indicators of disturbance, and formulated a Benthic Index of Biotic Integrity (B-IBI) based on those 10 metrics (Fore et al 1996). With a few minor alterations, this system was adopted by the Oregon Plan for Salmon and Watersheds for monitoring use state-wide (Oregon Plan 1999). This system examines the following metrics: 
- richness (number of taxa) for

- the entire sample

- Ephemeroptera (mayflies),

- Plecoptera (stoneflies), and

- Trichoptera (caddisflies).

- The Oregon DEQ has identified several macroinvertebrate taxa noteable for environmental tolerance and for sensitivity. Several metrics concern these indicator taxa:

- percentage of individuals in the sample belonging to tolerant taxa,

- percentage of individuals in the sample belonging to sediment-tolerant taxa,

- number of sensitive taxa, and

- number of sediment-sensitive taxa.

- The percentage of individuals in the sample belonging to the dominant taxon (the one with the largest number of individuals) is reflective of the diversity of the site: diversity tends to decrease with disturbance.

- The final metric is a modified version of Hilsenhoff's Biotic Index of the sensitivity of different taxa to nutrient pollution (Hilsenhoff 1987), whereby each taxon is rated between 0 (highly sensitive) and 10 (highly tolerant); the modified HBI is a weighted average, the sum of the number of individuals of each taxon multiplied by the rating for that taxon, divided by the number of organisms in the sample.

Once the individual attributes are evaluated, scoring each metric from 1 to 5 and determining an aggregate score between 10 and 50, stream condition for the site can be rated according to specific ranges of impairment (Table 1).

\begin{tabular}{l|l} 
Score & Stream Condition \\
\hline$>39$ & $\begin{array}{l}\text { No Impairment: passes level } 3 \text { assessment. } \\
\text { Indicates good diversity of invertebrates and stream conditions with little or no disturbance. }\end{array}$ \\
$\mathbf{3 0 - 3 9}$ & Slight Impairment: evidence of some impairment exists. \\
$\mathbf{2 0 - 2 9}$ & Moderate Impairment. clear evidence of disturbance exists. \\
$<20$ & Severe Impairment. conditions indicate a high level of disturbance.
\end{tabular}

Table 1. B-IBI score ranges, and the stream condition they imply

The results of the 2009 and 2010 sampling for each reach are shown in Table 2 and Table 3 , respectively. 


\begin{tabular}{|c|c|c|c|c|c|c|c|c|c|c|c|}
\hline Hood River B-IBI 2009 & & & & \multicolumn{2}{|c|}{ Reach 1} & \multicolumn{2}{|c|}{ Reach 2} & \multicolumn{2}{|c|}{ Reach 3} & \multicolumn{2}{|c|}{ Reach 4} \\
\hline$n=500 \quad$ scores: & 5 & 3 & 1 & value & score & values & score & value & score & value & score \\
\hline Taxa richness & $>35$ & $19-35$ & $<19$ & 23 & 3 & 23 & 3 & 22 & 3 & 25 & 3 \\
\hline Mayfly richness & $>8$ & $4-8$ & $<4$ & 7 & 3 & 6 & 3 & 5 & 3 & 9 & 5 \\
\hline Stonefly richness & $>5$ & 3-5 & $<3$ & 3 & 3 & 3 & 3 & 4 & 3 & 4 & 3 \\
\hline Caddisfly richness & $>8$ & $4-8$ & $<4$ & 5 & 3 & 5 & 3 & 6 & 3 & 4 & 3 \\
\hline Sensitive taxa & $>4$ & $2-4$ & $<2$ & 2 & 3 & 1 & 1 & 1 & 1 & 3 & 3 \\
\hline Sediment sensitive taxa & $>2$ & 1 & 0 & 2 & 5 & 2 & 5 & 2 & 5 & 2 & 5 \\
\hline Modified HBI & $<4.0$ & $4-5$ & $>5.0$ & 4.5 & 3 & 3.9 & 5 & 4.1 & 3 & 4 & 3 \\
\hline$\%$ Tolerant taxa & $<15$ & $15-45$ & $>45$ & 17.2 & 3 & 47.6 & 1 & 43.8 & 3 & 59.6 & 1 \\
\hline \% SedimentTol. taxa & $<10$ & $10-25$ & $>25$ & 0 & 5 & 1 & 5 & 0 & 5 & 2.4 & 5 \\
\hline$\%$ Dominant & $<20$ & $20-40$ & $>40$ & 50.4 & 1 & 47.4 & 1 & 43.8 & 1 & 59.4 & 1 \\
\hline tota & & & & & 32 & & 30 & & 30 & & 32 \\
\hline
\end{tabular}

Table 2. 2009 B-IBI metrics, individual scores, and aggregate scores for all four study reaches before dam removal.

In 2009, before dam removal began, B-IBI scores (Table 2) were consistent throughout the study area, between 32 and 30 - at the very bottom end of the "slightly impaired" range (Table 1). A slight decrease in score occurred between the "control" site (Reach 1, above the Dam) and sites downstream, but there was a rebound in the final site (Reach 4, the Powerhouse) to the same value as Reach 1.

Further examination of the individual metrics reveals some notable patterns. Percentage of Tolerant Taxa increases steadily with movement downstream (Figure 4), while number of Sensitive Taxa decreases in midstream and rebounds downstream (Figure 5). Numbers of Sediment Sensitive Taxa are high (Figure 5), and Percentages of Sediment Tolerant Taxa are low (Figure 4), throughout the system. Modified Hilsenhoff Biotic Index, indicating level of nutrient pollution (Figure 6), actually decreases below the above-dam reference site, dropping from the moderate value of 4.5 and hovering around the threshold value of 4.0: this might indicate that some upstream agricultural nutrient pollution has been sequestered by the dam.

Taken together, these biotic data would indicate that some form of disturbance was accumulating with progression downstream in the dammed system, but that it was apparently not sediment (which remained low throughout), nor was it likely to be fertilizer-derived nutrient pollution (which declined from moderate to low-moderate). 


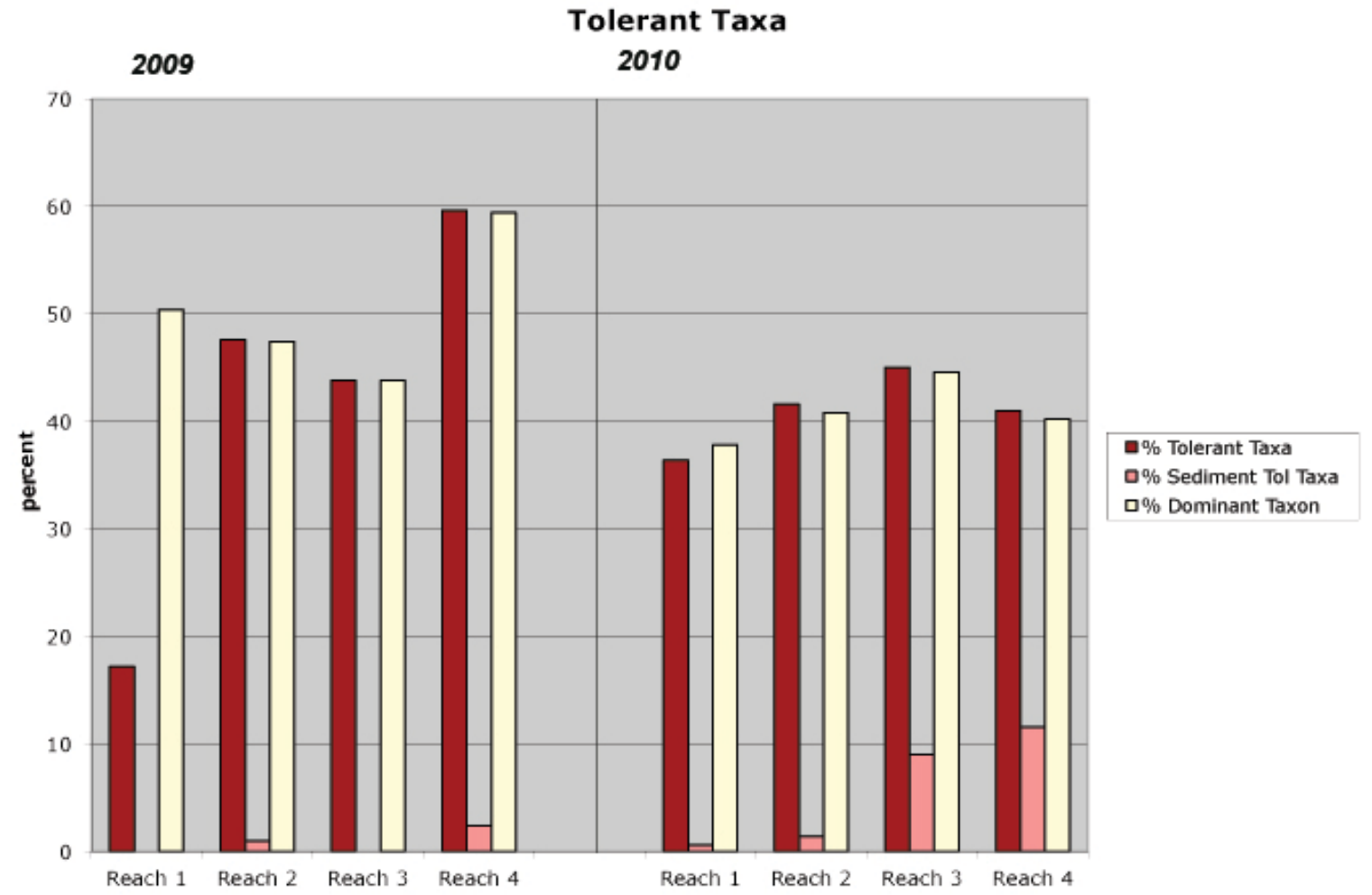

Figure 4. Percentages of each composited and subsampled Hood River reach sample $(n=500)$ belonging to ODEQ listed Tolerant taxa (brown), Sediment Tolerant taxa (salmon), and to the Dominant (most numerous single) taxon (yellow) in 2009 and 2010.

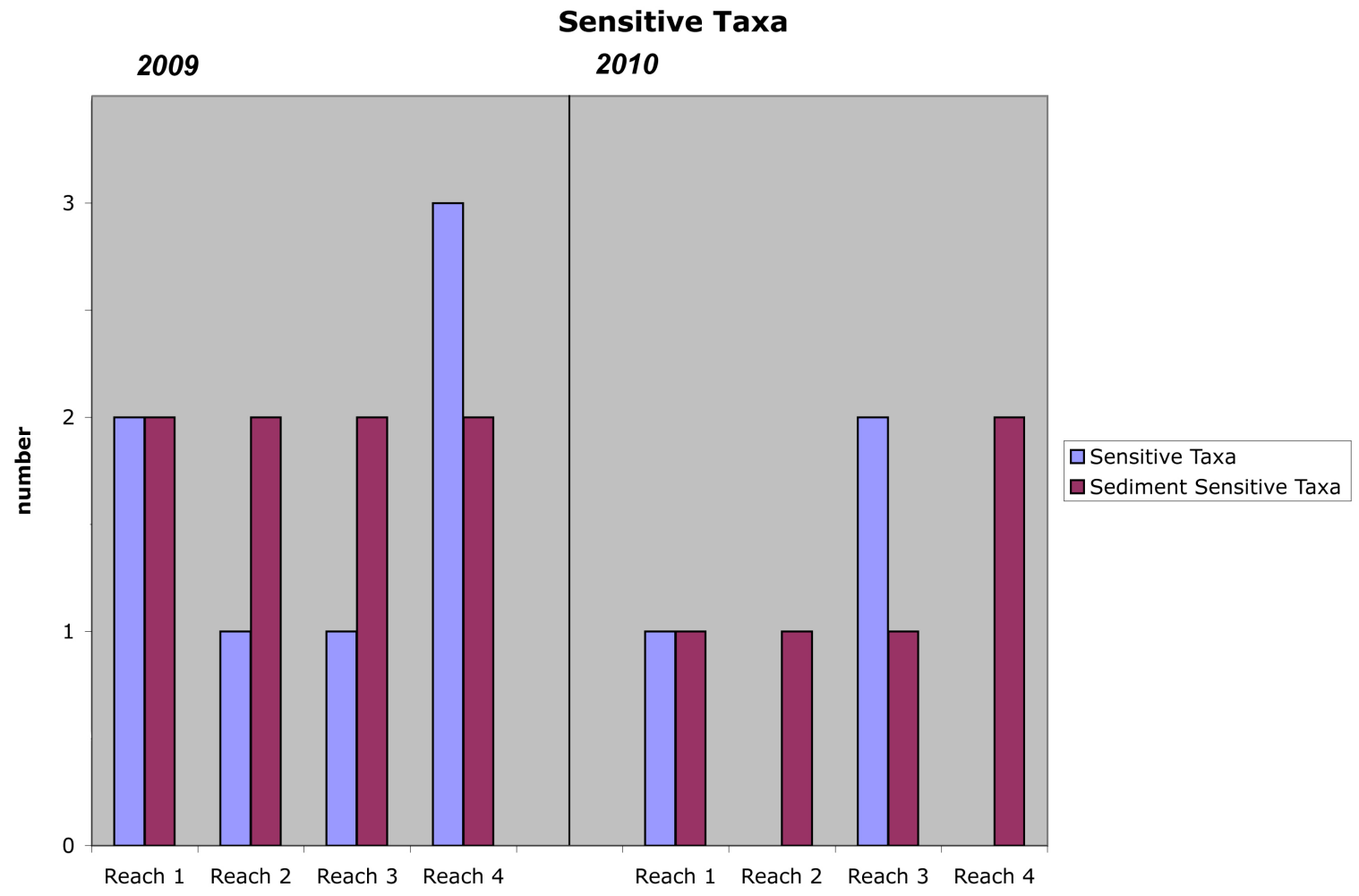

Figure 5. Number of ODEQ listed Sensitive taxa (purple) and Sediment Sensitive taxa (maroon) in each composited and subsampled Hood River reach sample $(\mathrm{n}=500)$ in 2009 and 2010. 


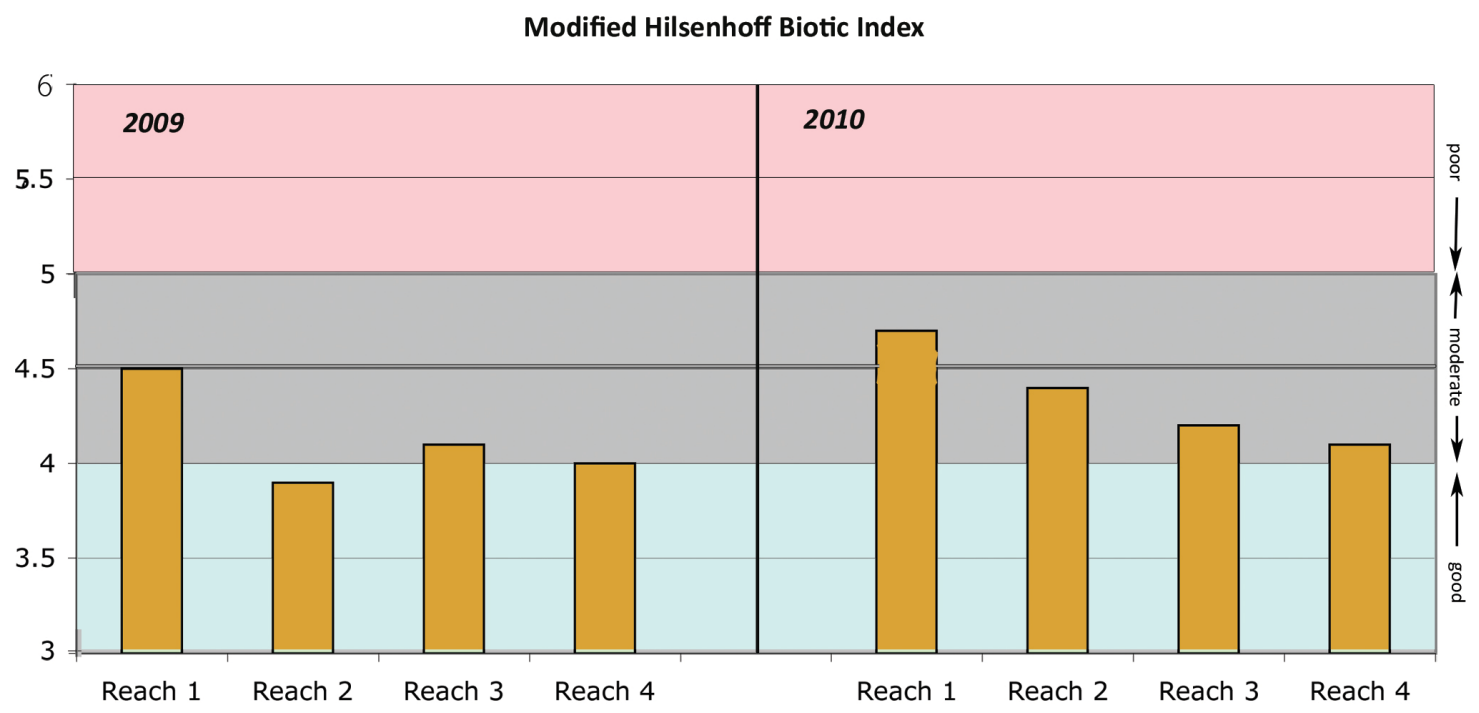

Figure 6. Modified Hilsenhoff Biotic Index for all composited and subsampled Hood River reach samples $(n=500)$, a weighted average indicating sensitivity to nutrient (primarily nitrogen and phosphorus) pollution. Higher than 5 indicates poor (high) nutrient levels, lower than 4 indicates good (low) levels, and 4-5 indicates moderate levels.

During the process of dam removal, in 2010 all B-IBI scores were depressed (Table 3), starting with a lower score in the control reach (Reach 1 - Above the Dam) that put it precisely on the threshold of moderate impairment: the downstream reaches were all "moderately impaired", indicating clear evidence of disturbance, with the final downstream reach approaching the "severe impairment" threshold (Table 1).

\begin{tabular}{|c|c|c|c|c|c|c|c|c|c|c|c|}
\hline \multicolumn{4}{|l|}{ Hood River B-IBI $\quad 2010$} & \multicolumn{2}{|c|}{ Reach 1} & \multicolumn{2}{|c|}{ Reach 2} & \multicolumn{2}{|c|}{ Reach 3} & \multicolumn{2}{|c|}{ Reach 4} \\
\hline$n=500 \quad$ scores: & 5 & 3 & 1 & value & score & value:s: & score & value & score & value & score \\
\hline Taxa richness & $>35$ & $19-35$ & $<19$ & 22 & 3 & 23 & 3 & 20 & 3 & 18 & 1 \\
\hline Mayfly richness & $>8$ & $4-8$ & $<4$ & 6 & 3 & 3 & 1 & 6 & 3 & 3 & 1 \\
\hline Stonefly richness & $>5$ & $3-5$ & $<3$ & 3 & 3 & 3 & 3 & 1 & 1 & 2 & 1 \\
\hline Caddisfly richness & $>8$ & $4-8$ & $<4$ & 5 & 3 & 5 & 3 & 4 & 3 & 5 & 3 \\
\hline Sensitive taxa & $>4$ & $2-4$ & $<2$ & 1 & 1 & 0 & 1 & 2 & 3 & 0 & 1 \\
\hline Sediment sensitive taxa & $>2$ & 1 & 0 & 1 & 3 & 1 & 3 & 1 & 3 & 2 & 5 \\
\hline Modified HBI & $<4.0$ & $4-5$ & $>5.0$ & 4.7 & 3 & 4.4 & 3 & 4.2 & 3 & 4.1 & 3 \\
\hline$\%$ Tolerant taxa & $<15$ & $15-45$ & $>45$ & 36.4 & 3 & 41.6 & 3 & 45 & 1 & 41 & 3 \\
\hline$\%$ SedimentTol. taxa & $<10$ & $10-25$ & $>25$ & 0.6 & 5 & 1.4 & 5 & 9 & 5 & 11.6 & 3 \\
\hline$\%$ Dominant & $<20$ & $20-40$ & $>40$ & 37.8 & 3 & 40.8 & 1 & 44.6 & 1 & 40.2 & 1 \\
\hline tota & & & & & 30 & & 26 & & 26 & & 22 \\
\hline
\end{tabular}

Table 3. 2010 B-IBI metrics, individual scores, and aggregate scores for all four study reaches during the dam removal process. 
Declines in a number of specific metrics are responsible for these greater 2010 impairment ratings. Declining richness in the below-dam reaches (Figure 7), particularly mayfly richness and, in the lower two sites, stonefly richness, is a major factor. A decrease in the number of Sensitive taxa is evident (Figure 5), though the percentage of Tolerant taxa decreased somewhat (Figure 4) - except in the control reach, where that percentage doubled. (These Tolerant taxa changes are entirely the result of changes in the abundance of a single taxon, the tolerant caddisfly Hydropsyche.) Percentage of Sediment Tolerant taxa increased significantly throughout the system (Figure 4), and to an increasingly greater degree downstream; number of Sediment Sensitive taxa decreased in all but the most downstream site (Figure 5). Hilsenhoff Biotic Index is a bit elevated above 2009 at each station (Figure 6): this could indicate a release of nutrients from the impounded sediment. The Dominant taxon in Reach 1 is Baetis tricaudatus, and in all other reaches it is Hydropsyche. Dominance changes are entirely the result of changes in the abundance of these two taxa.

Taken together, it seems the dam removal process has degraded habitat quality downstream by increasing sedimentation; that the degree of degradation may be greater than the relatively modest effect of sedimentation, perhaps because of the release of nutrient and/or pesticide residue in the dam impoundment; and that some systemic degradation may have also been introduced from further upstream in 2010, possibly a higher level of nutrient pollution than in 2009.

There is some possibility that the "control" reach (Reach 1 - Above Powerdale) may have been influenced by the dam removal process, but by September of 2010 there was no evidence of such influence onsite. The reach seemed sufficiently removed from the Dam and its excavation processes that there was no apparent effect of the construction project on the control reach on the survey day. The construction contractor, Weekly Brothers, Inc. of Idleyld Park, Oregon, states that, in accordance with FERC guidelines, no borrow pits or other excavations were conducted upstream of the dam, and that all demolished concrete was buried in areas hydrologically isolated from the river (Nick Weekly, personal communication, 2011; FERC 2005). 


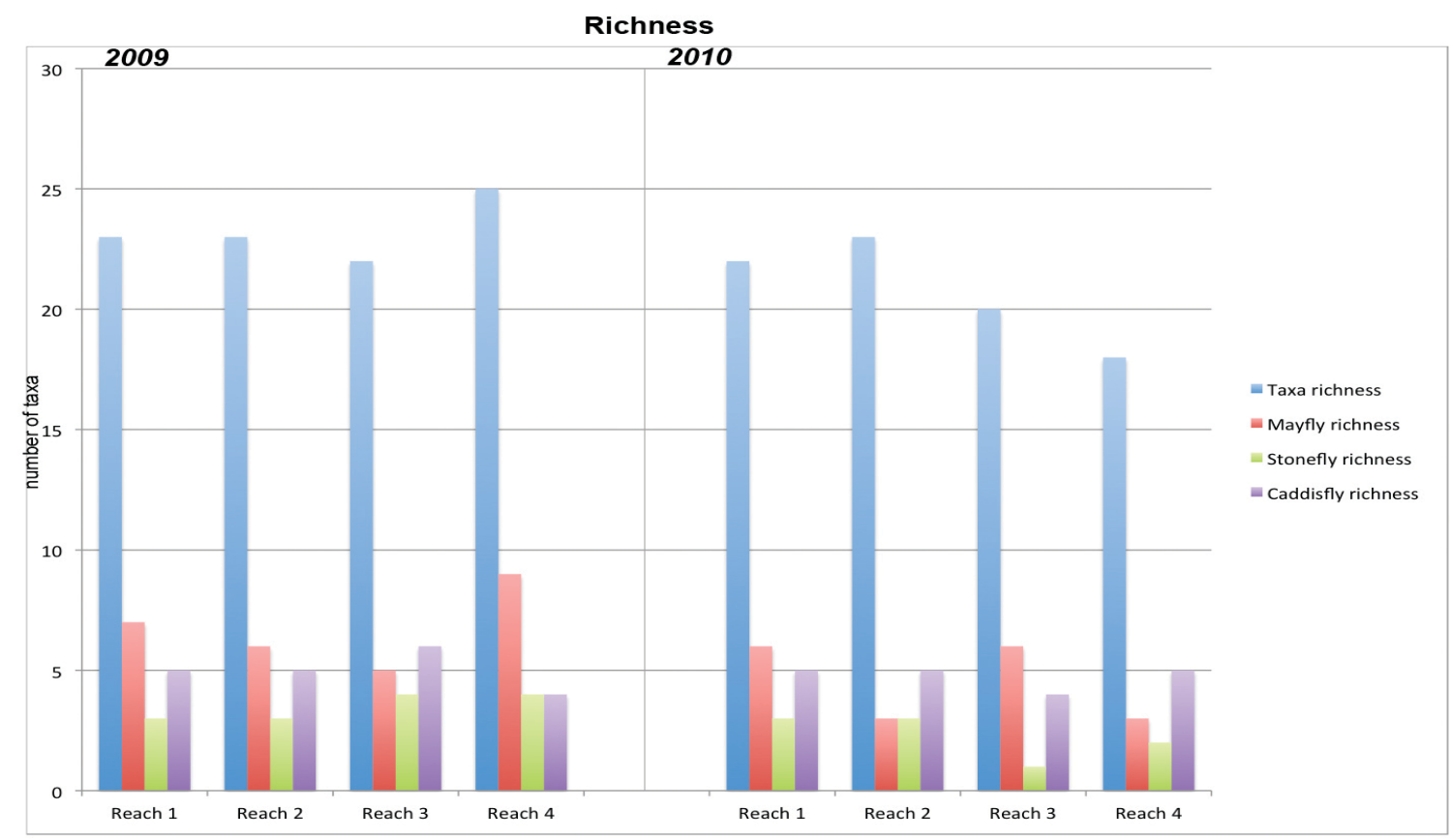

Figure 7. Richness (number of taxa) for the entire sample (blue), mayflies (Ephemeroptera) (red), stoneflies (Plecoptera) (green), and caddisflies (Trichoptera) (purple) for each composited and subsampled reach sample $(\mathrm{n}=500)$ in 2009 and 2010.

\section{Multivariate}

Multivariate analysis uses statistical modeling to predict the taxa that would be found in an undisturbed stream similar to the river under study, and divides the number of observed taxa (found by randomly sampling the habitat) by the number of expected taxa (predicted by the model) to yield a ratio, $\mathrm{O}$ over E. This number serves as a communitylevel measure of biological condition: a low $\mathrm{O} / \mathrm{E}$ value, with fewer taxa than predicted, indicates a disturbed stream, while a value closer to 1.0 suggests a more pristine habitat. Developing a model of this type requires extensive sampling of reference streams, using cluster analysis to determine which characteristic variables of a stream are most predictive of the taxa to be expected. The first such model was the RIVPACS system ("River InVertebrate Prediction and Classification System") developed for Great Britain (Wright 1994.) The AusRivAS model (Smith et al. 1999) in Australia was developed shortly thereafter; models have more recently been developed in New Zealand (Joy \& Death 2003) and Canada (Reese et al. 2001), and in regions around the United States, including Wyoming, North Carolina, Ohio, and Maine (Hargett et al. 2005).

The Oregon Department of Environmental Quality has developed a predictive model for macroinvertebrate communities in streams in Oregon, the PREDictive Assessment Tool for ORegon, generally referred to by its sometimes confusing acronym PREDATOR (Hubler 2008). Three regional models have been developed: the study site falls within the Western Cordillera + Columbia Plateau region. O/E benchmark values have been determined which describe the biological condition of a sample, based on the $10^{\text {th }}$ and $25^{\text {th }}$ percentile of reference sites (Table 4). 


\begin{tabular}{|c|c|c|c|}
\hline $\begin{array}{c}\text { Biological } \\
\text { Condition } \\
\text { Class }\end{array}$ & $\begin{array}{c}\text { Reference } \\
\text { percentile }\end{array}$ & O/E & $\begin{array}{c}\text { \% Common } \\
\text { Taxa } \\
\text { Loss } / \text { Gain }\end{array}$ \\
\hline Most disturbed & $\leq 10^{\text {th }}$ & $\leq 0.78$ & $\leq 22 \%$ loss \\
\hline Moderately disturbed & $>10^{\text {th }}$ to $25^{\text {th }}$ & $0.79-0.92$ & $8-21 \%$ loss \\
\hline Least disturbed & $>25^{\text {th }}$ to $95^{\text {th }}$ & $0.93-1.23$ & $0-7 \%$ loss, $0-23 \%$ gain \\
\hline Enriched & $>95^{\text {th }}$ & $>1.23$ & $>23 \%$ gain \\
\hline
\end{tabular}

Table 4. O/E benchmarks for describing biological condition for the predictive PREDATOR model for the Western Cordillera and Columbia Plateau region. (after Hubler 2008)

PREDATOR values were calculated using the software at the website of the Western Center for Monitoring \& Assessment of Freshwater Ecosystems, at Utah State University (http://cnr.usu.edu/wmc/). The O/E values so calculated place every lower Hood River site but one in the Most Disturbed cohort, less than $10^{\text {th }}$ percentile of reference sites (Table 5).

\begin{tabular}{|c|c|c|c|}
\hline Sites & O & E & O/E \\
\hline 2009 & & & \\
\hline Reach 1 - Above Powerdale & 10 & 13.608792 & 0.734819 \\
\hline Reach 2 - Experiment Station & 11 & 13.678322 & 0.804192 \\
\hline Reach 3 - Flume Crossing & 10 & 13.714565 & 0.729152 \\
\hline Reach 4 - Powerhouse & 10 & 13.718905 & 0.728921 \\
\hline 2010 & 9 & 13.718905 & 0.728921 \\
\hline Reach 4 - Powerhouse & 9 & 13.678322 & 0.584867 \\
\hline Reach 2 - Below Powerdale & 8 & 13.71465 & 0.656237 \\
\hline Reach 3 - Flume Crossing & 9 & 108792 & 0.661337 \\
\hline Reach 1 - Above Powerdale & 9 & & \\
\hline
\end{tabular}

Table 5. Results from the PREDATOR predictive model for 2009 and 2010 Hood River sites: number of Observed taxa $(\mathrm{O})$, the Expected number of taxa predicted by the model $(\mathrm{E})$, and the ratio of Observed to Expected taxa $(\mathrm{O} / \mathrm{E})$. 
It must be noted that the PREDATOR software features a statistical test to guard against inappropriate extrapolation to sites not embraced by the model as constructed - to ensure that predictor values measured at the sites are within a statistically acceptable range of values measured at the reference sites. All eight of these sites do not pass this test. The example of inappropriate extrapolation given by the model's website is the application of a model built for small streams to sites on a larger stream - precisely the situation here.

Nonetheless, the model flags such sites but still generates $\mathrm{O} / \mathrm{E}$ figures, allowing the researcher to make the final decision as to the extrapolation's validity. With the suggestion of the model's creator, Shannon Hubler, that sampling the wadeable margins of a large river could yield applicable data, it seems appropriate to cautiously accept the $\mathrm{O} / \mathrm{E}$ figures, realizing they may over- or under-estimate the sites' condition in comparison to other sites in the region; PREDATOR's rejection of these sites may be as much the product of their location at the edge of the model's geographical range as any true biological dissimilarity. The validity of these PREDATOR figures for comparing sites within the lower Hood River basin over time seems more profound, particularly in regards to our primary purpose, examining the response of habitat to dam removal.

Furthermore, ODEQ has used PREDATOR figures derived from sites throughout the lower Hood River basin, both above and below our collection sites, for purposes of habitat analysis and comparison. ODEQ's research, from 2000-2008, found, as this study did, increasing biological degradation in the downstream direction. At the footbridge downstream of I-84, just before Hood River enters the Columbia, average PREDATOR scores were 0.49 , far lower than the present study's lowest figures. Other collection sites included the Hood River tributary Neal Creek, which enters Hood River just downstream of Reach 1, and which showed a very healthy average PREDATOR value of 0.99 above the agricultural diversion, decreasing to 0.75 and 0.77 below it; and Lenz Creek, a tributary of Neal Creek, which rated 0.62 at the mouth. PREDATOR scores dropped with spring herbicide spraying and rebounded some months later (Hubler \& Borisenko 2008).

Most of the the current study's sampling sites show a significant decline in O/E value from 2009, before the beginning of dam removal, to 2010, in the midst of the removal process (Table 5). The exception is Reach 4, the Powerhouse site, whose O/E number is unchanged from the previous year, despite the precipitous decline of its B-IBI number. Reach 2, due to logistical complications of the construction site, was a different location in the first and second sampling years. The 2009 site was the deepest and fastest-flowing of all the sites, with a substrate of boulders and large cobbles; its similarity to more mountainous reference sites may explain its assessment as "moderately disturbed" rather than "most disturbed", even if at the very low end of that superior range. The 2010 site was shallower and slower moving, with gravel to cobble substrate, a vegetated sandbar, and a higher percentage of fine sediment; this, combined with its position $2 \mathrm{~km}$ closer to the dam-demolition project than the 2009 site, may explain its very low PREDATOR number. 


\section{Temperature and Sediment Optima}

The Probability Matrix output of the PREDATOR model identifies "missing" taxa, whose presence the model predicted but which were not discovered in the sample, and "replacement" taxa, which the model did not predict but which did appear in the sample. This information can be used to tease out possible causes for stream degradation. The Oregon Department of Environmental Quality has determined maximum summer temperature and fine sediment optima for most aquatic invertebrate taxa in Oregon (Huff et al. 2006). The relative roles of temperature and sediment in habitat quality can sometimes be inferred by comparing the optima of missing taxa to those of replacement taxa (Hubler 2008). This is a qualitative analytical technique, in which the optima are displayed graphically and compared visually: the number of replications is insufficient for effective statistical evaluation (S. Hubler, personal communication, 2011).

In general, degraded streams are expected to be warmer than pristine streams and/or to have a higher sediment content. The temperature and sediment optima for the study sites' Hood River reaches, surprisingly, tended to be slightly colder and to have a slightly lower sediment content than the PREDATOR model predicted - though with sufficient overlap between optimal ranges to suggest that this may not be a significant effect (S. Hubler, personal communication, 2011). The seemingly lower optimal ranges may also be influenced by the sites' location at the geographical fringe of the predictive model.

Hood River's depth and flow may be sufficient, in combination with the frigidity of its largely glacial water sources, to lower its average temperature and sedimentation relative to the shallower, wadeable streams for which the PREDATOR model was built. On the other hand, the 3.9 stream miles between the Powerhouse and the Dam are, in fact, listed on the ODEQ's 1998 303(d) list for temperature exceeding state water quality standards (Figure 8), so the presumption of elevated temperature degradation in this biologically impaired river is not unfounded. 


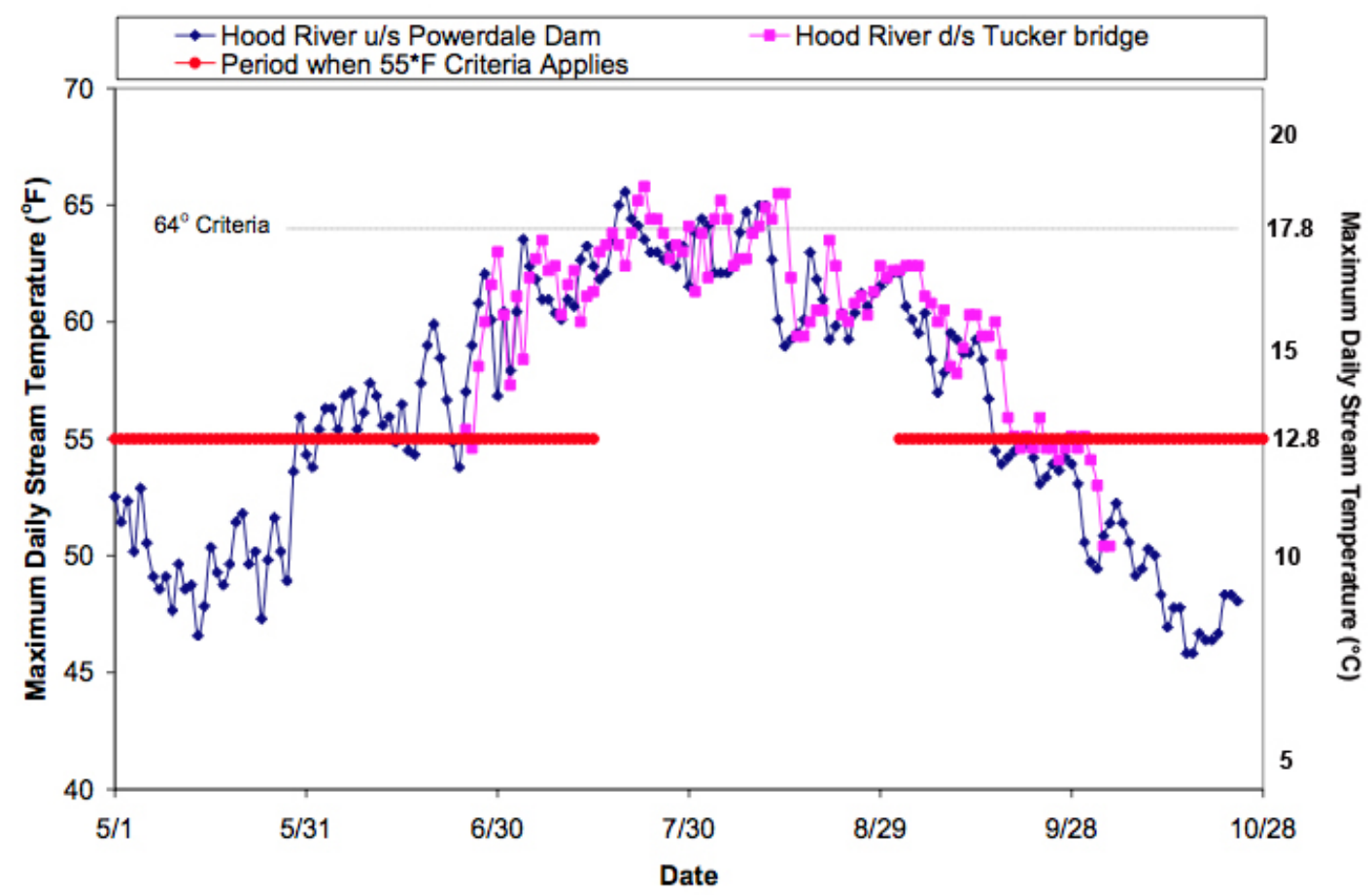

Figure 8. 1998 Observed Daily Maximum Temperatures in Hood River, upstream (u/s) of Powerdale Dam, and downstream (d/s) of Tucker Bridge [approximately $2.5 \mathrm{~km}$ upstream of Powerdale Dam] (ODEQ 2001).

Boxplots of temperature optima for the "control reach", Above Powerdale Dam (Figure 9) show a slight displacement among replacement taxa towards a preference for colder temperatures in 2009, and somewhat less so towards a preference for lower percentage of fine particles. In both cases, overlap between the ranges for missing and replacement taxa is substantial. Optimal ranges for 2010 show no clear displacement in any direction.

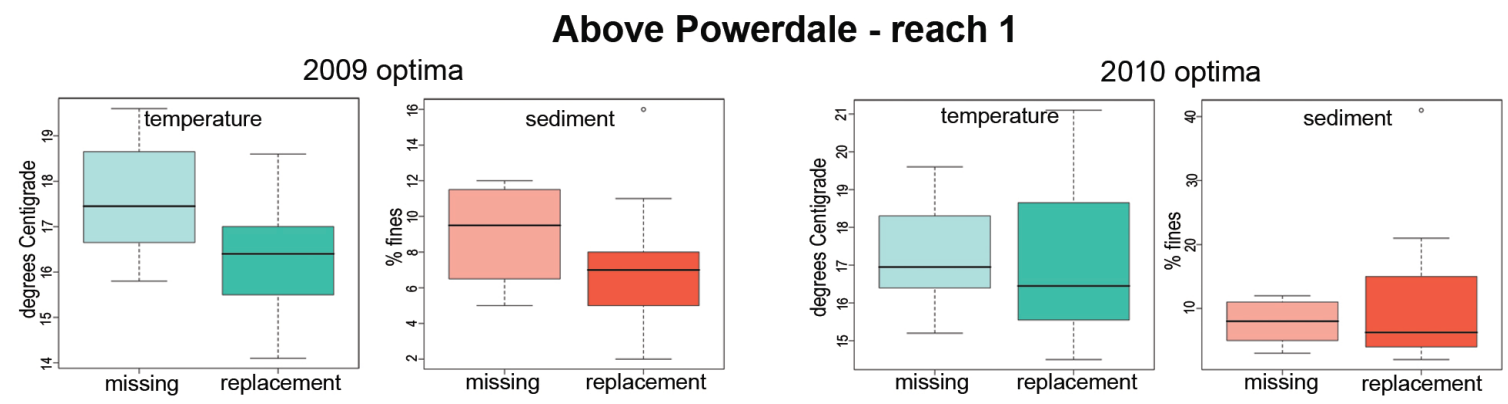

Figure 9. Temperature and sediment optima (from ODEQ) of missing versus replacement taxa (as determined by the PREDATOR model) for Reach 1, Above Powerdale, in 2009 and 2010.

Temperature optima for all taxa are calculated based on the warmest 7-day average of the season (Huff et al. 2006). Missing taxa appear to show a mean optimum very close to that value for 1998 (Figure 8 \& 10): the fact that replacement species show a lower mean optimum may conceivably mean that Hood River has cooled in more recent years. My measurements found a mean temperature for this site of $14^{\circ} \mathrm{C}$ for 2009 , quite in the 
appropriate range for the time of year relative to 1998 , and of $11.5^{\circ} \mathrm{C}$ in 2010 , unseasonable cold relative to the 1998 figures (Figure 8). More current year-round temperature data are not available.

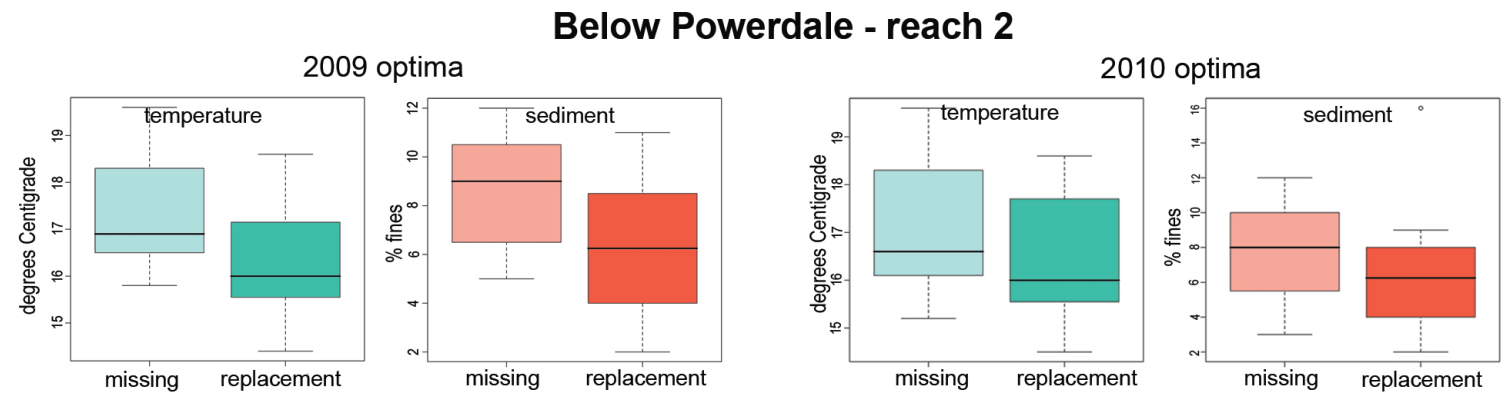

Figure 10. Temperature and sediment optima (from ODEQ) of missing versus replacement taxa (as determined by the PREDATOR model) for Reach 2, Below Powerdale, in 2009 and 2010.

Even though the 2009 and 2010 sample sites were in different locations, comparison of the sites Below Powerdale (Figure 10) show similar degrees of displacement, of both cooler temperature optima and lower fine sediment percentages, among replacement taxa - again, not to a degree that would categorically indicate a large ecological role for either parameter. Field measurements during sampling yielded a mean of $16^{\circ} \mathrm{C}$ for $2009,12^{\circ} \mathrm{C}$ in 2010 .

Disparities between missing and replacement taxa were perhaps the broadest for the Flume Crossing site (Figure 11) in temperature in 2009, somewhat less in 2010; replacement taxa showed a relatively strong preference for lower sediment levels, particularly in 2010. The degree of seperation is still probably not sufficient to be considered significant. Field temperatures were $15^{\circ} \mathrm{C}$ in $2009,11^{\circ} \mathrm{C}$ in 2010 .

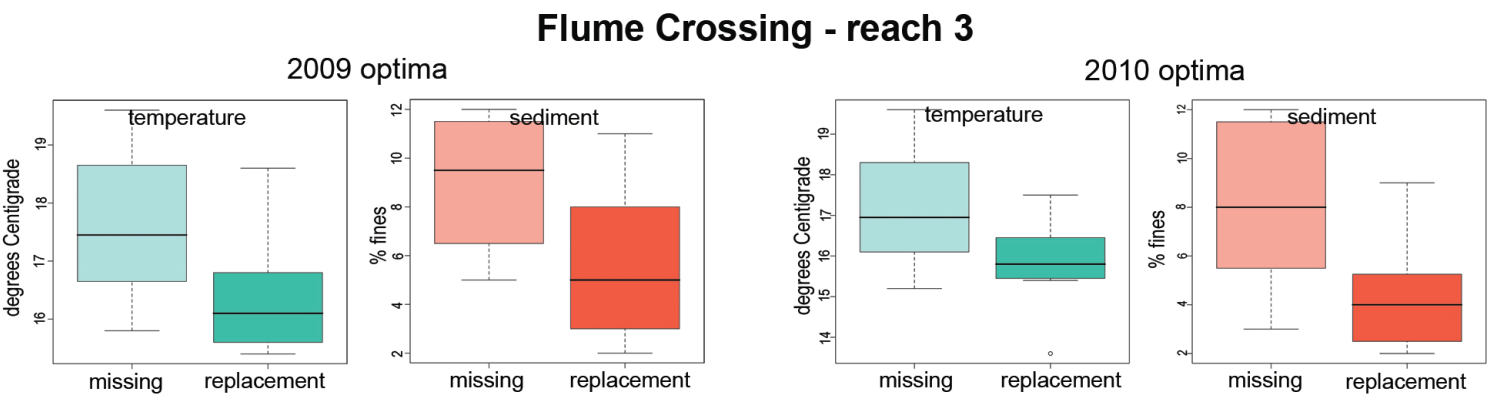

Figure 11. Temperature and sediment optima (from ODEQ) of missing versus replacement taxa (as determined by the PREDATOR model) for Reach 3, Flume Crossing, in 2009 and 2010.

The Powerhouse site optima for both temperature and sediment showed more separation between missing and replacement taxa in 2009 than in 2010 (Figure 12). The slightly higher optima in the dam removal year may be indicative of disturbance, but again the 
effect may be too small to be significant. Field temperature measurements were $17^{\circ} \mathrm{C}$ in $2009,13^{\circ} \mathrm{C}$ in 2010 .

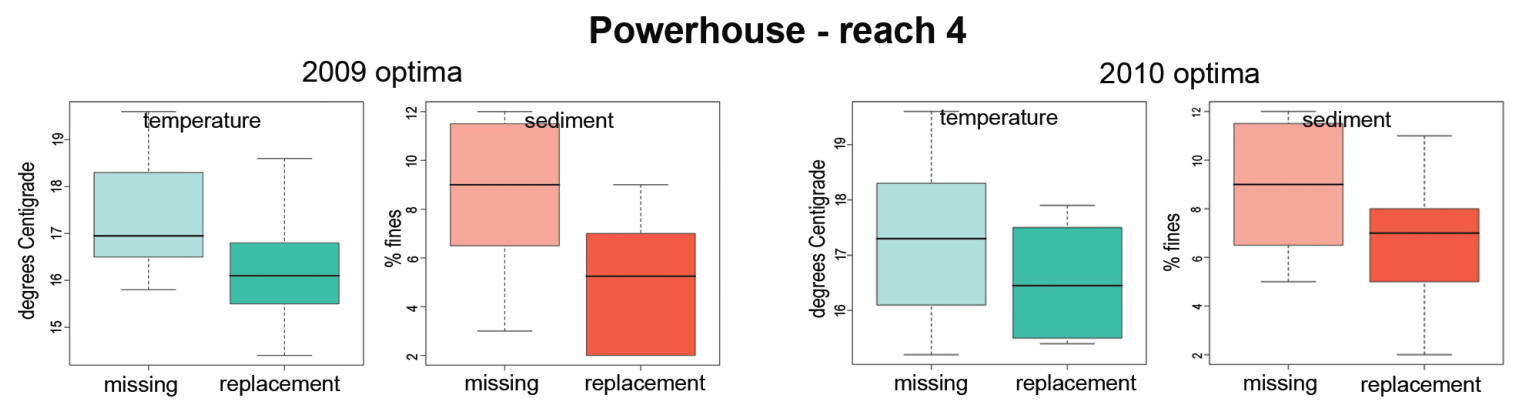

Figure 12. Temperature and sediment optima (from ODEQ) of missing versus replacement taxa (as determined by the PREDATOR model) for Reach 4, the Powerhouse, in 2009 and 2010.

\section{Functional feeding groups}

Much research has been carried out recently in the use of functional feeding groups (FFG) - the role specific taxa play in the structure and flow of energy and material in an aquatic system - as a tool to examine the ecology of freshwater habitats. The thrust of many of these studies has been that, as a field technique, identification of an organism's feeding mechanism is far easier, faster, and cheaper than complete taxonomic identification (Merritt et al 2008). Though such detailed identification has already been performed on these samples, trophic analysis is still a useful avenue to pursue.

Aquatic insects feed themselves with a wide range of different strategies. Shredders chew coarse particulate organic material (CPOM, particles $>1.0 \mathrm{~mm})$, primarily originating as vascular plant tissue from outside the aquatic environment (riparian leaf fall). Collector/Gatherers are deposit feeders, gathering loose particles of decomposing fine particulate organic material (FPOM, 0.05-1.0 mm) in depositional areas, as well as algae, bacteria, and feces. Collector/Filterers are suspension feeders, filtering finer particles of FPOM (0.01-1.0) and small organisms from the water column, either using anatomical adaptations or by secreting mucous nets; they are generally found on firmer, less depositional substrate than collector/gatheres. Scrapers graze on periphyton on rock or wood surfaces, eating algae, bacteria, microflora and fauna, as well as associated detritus and feces. Predators capture living animal prey and ingest all or part of the prey organism or its bodily fluids.

The River Continuum principle (Vannote et al. 1980) predicts that certain functional feeding groups will be found in particular regions of a river system. It is expected, for instance, that the insect population of a river's headwaters will consist of a large proportion of shredders, because leaf fall is the primary source of nutrition in these shady, canopy-enclosed waters. Collector/gatherers increase in numbers further downstream, gathering particles the shredders have broken up, followed by collector/filterers as the particles become smaller. Scrapers thrive on algae that grow in the sunny middle reaches. A large dam often "resets" the continuum, with a small spillway resembling the narrow 
headwaters of an undammed system; however, a smaller dam like Powerdale, close to the river's mouth, does not appear to have as pronounced a resetting effect.

Pre-dam removal, in 2009, Hood River seems to have followed the predictions of the River Continuum concept quite closely (Figure 13). Shredders were rare in these wide, deep waters, where some riparian leaf fall occurs but is a relatively minor input compared to the large influxes of detritus from further upstream. Scrapers were a small but significant fraction of the population in the most upriver site, where conditions are presumably closest to midriver, and declined steadily as we moved downstream. Collector/gatherers started at Reach 1 as the largest single cohort, and gradually decreased in importance downstream as collector filterers correspondingly increased, in concert with the presumed decrease in particle size and increase in depositional substrate. As in previous analyses (p. 18 above), these changes in proportion are almost entirely the result of shifts in the abundance of the two most dominant taxa, the mayfly gatherer Baetis tricaudatus and the caddisfly filterer Hydropsyche.

During dam removal in 2010, there were some changes in the proportions of functional feeding groups. Abundance of predators and scrapers declined. The relative proportions of gatherers and filterers did not shift in the same complimentary way in sites further downstream; this could indicate that dam-removal disturbance increased the amount of depositional FPOM in the system, relative to that suspended in the water column.

Functional Feeding Groups

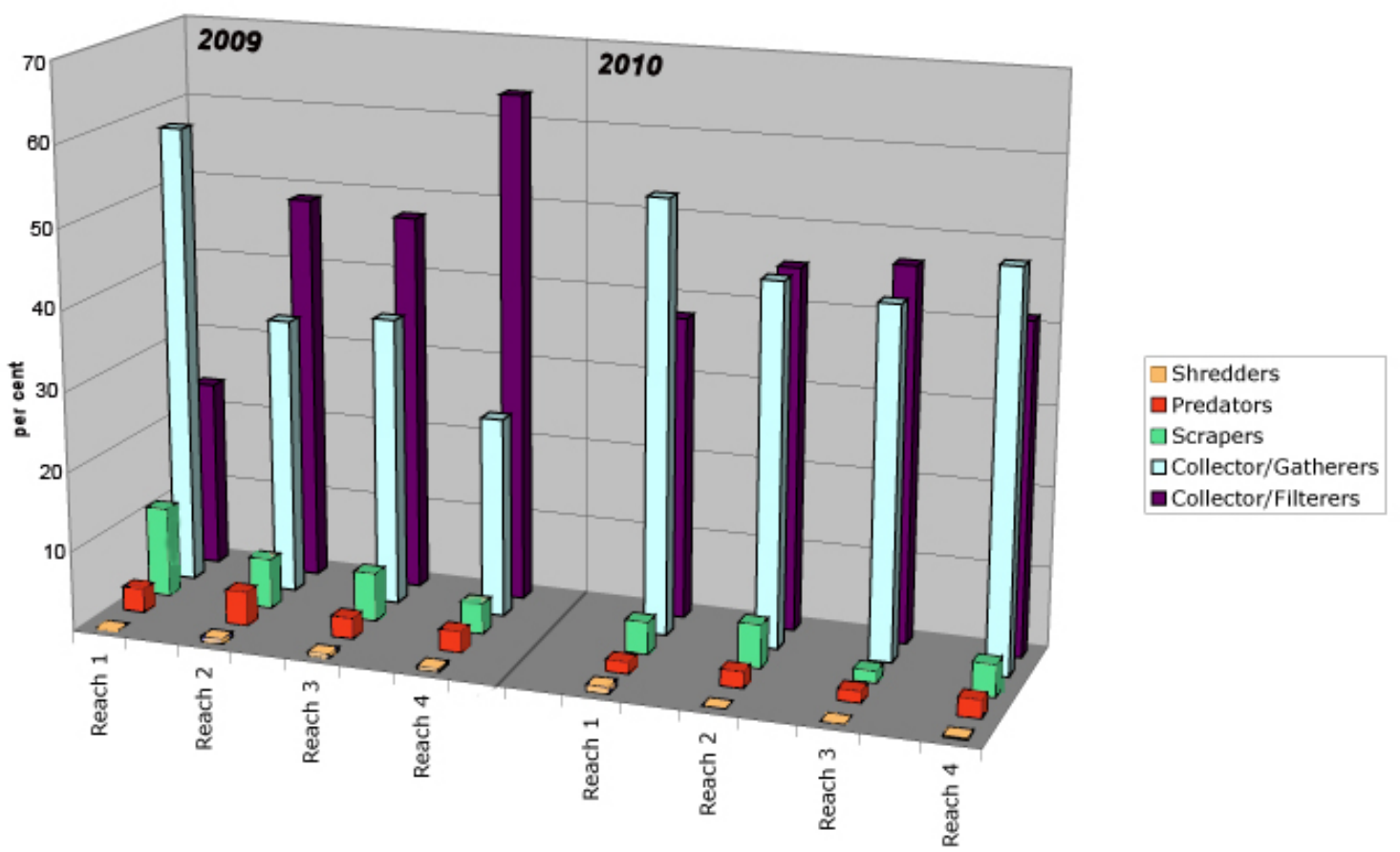

Figure 13. Percentages of each composited and subsampled reach $(n=500)$ belonging to each of five major functional feeding groups of aquatic macro-invertebrates: Shredders (gold), Predators (red); Scrapers (green), Collector/Gatherers (blue), and Collector/Filterers (purple). For 2009 and 2010. 
The relative proportions of these groups reflect any changes in ecosystem condition that affects the nutritional resource base, and can be used as a surrogate for some ecosystem attributes (Merritt et al. 2008, Cummins et al. 2005). A number of indices have been developed that focus on these attributes (Table 6); while the validity of these indices for accurate ecological analysis may be compromised in highly impacted systems, strict correspondences between FFG surrogates and direct measurement only being found in sites with taxa richness greater than 20 (Andrade 2006), all but one of these sites do in fact meet that criterion. In any case, FFG ratios are useful as descriptors and comparitors of ecological conditions, even if they do not always do so with laboratory accuracy.

\begin{tabular}{|c|c|c|c|c|c|c|c|c|}
\hline & \multicolumn{4}{|l|}{2009} & \multicolumn{4}{|l|}{2010} \\
\hline & $\begin{array}{l}\text { Reach } \\
1\end{array}$ & $\begin{array}{l}\text { Reach } \\
2\end{array}$ & $\begin{array}{l}\text { Reach } \\
3\end{array}$ & $\begin{array}{l}\text { Reac } \\
\text { h } 4\end{array}$ & $\begin{array}{l}\text { Reach } \\
1\end{array}$ & $\begin{array}{l}\text { Reach } \\
2\end{array}$ & $\begin{array}{l}\text { Reach } \\
3\end{array}$ & $\begin{array}{l}\text { Reach } \\
4\end{array}$ \\
\hline $\begin{array}{l}\text { Auto/Hetero- } \\
\text { trophic Index }\end{array}$ & 0.11 & 0.07 & 0.06 & 0.04 & 0.04 & 0.06 & 0.01 & 0.04 \\
\hline Shredder Index & 0.00 & 0.01 & 0.00 & 0.00 & 0.01 & 0.00 & 0.00 & 0.00 \\
\hline $\begin{array}{l}\text { Filtering } \\
\text { Collector Index }\end{array}$ & 0.33 & 1.08 & 1.06 & 2.03 & 0.63 & 0.86 & 0.94 & 0.74 \\
\hline $\begin{array}{l}\text { Channel } \\
\text { Stability Index }\end{array}$ & 0.48 & 1.20 & 1.18 & 2.12 & 0.69 & 0.96 & 0.97 & 0.81 \\
\hline $\begin{array}{l}\text { Predator-Prey } \\
\text { Index }\end{array}$ & 0.03 & 0.04 & 0.03 & 0.03 & 0.01 & 0.02 & 0.01 & 0.02 \\
\hline
\end{tabular}

Table 6. Ratios of functional feeding groups for each composited and subsampled study reach ( $\mathrm{n}=500)$ in 2009 and 2010.

Autotrophic/Heterotrophic Index. (ratio: Scrapers to [Shredders + Total Collectors].) A surrogate for $\mathrm{P} / \mathrm{R}$, the ratio of gross primary production (total photosynthetic plant production) to community respiration in the system, indicating whether the primary source of resource input to the river is internal (autochthonous) or external (allochthonous). An autotrophic ecosystem has a value for this index $>0.75$ (Merritt et al. 2002): the vanishingly small values found throughout the study site (Table 6) indicate that lower Hood River is a strongly heterotrophic ecosystem - that the vast majority of production in the river occurs outside, rather than inside, the stream channel. All sites except Reach 4 show a decline in 2010; Reach 1, the "control" site, showed significantly higher levels of primary production in 2009 than any other site in either year.

Shredder Index. (ratio: Shredders to Total Collectors.) This serves as a surrogate for the ratio of coarse particulate organic matter (CPOM) to fine particulate organic matter (FPOM), that is, the degree to which vegetative matter entering the stream has been processed into particles $<1 \mathrm{~mm}$. This index is generally a seasonally variable measurement, with a shredder population varying relative to autumn leaf fall. Shredders are only able to consume leaf litter that has been "conditioned", that is, partially broken down by micro-organisms, so that it takes weeks to months for a fallen leaf to become available food for shredder species; conditioning times vary for different plant species, 
with alder (Alnus rubra) among the fastest, and Douglas fir (Pseudotsuga menziesii) among the slowest (Cummins et al. 1989). Casual observation suggested that the majority of leaves found in these samples did, in fact, belong to these two species. Presumably shredder populations would peak at a point in the year when the autumn alder leaf-fall is at maximum availability; in contrast, the constant presence of slow-conditioning, nondeciduous Douglas fir leaves should provide a constant supply of food for shredders (Cummins et al. 1989). That being said, the River Continuum concept (Vannote et al. 1980) would predict a minor role for shredders at the sampling sites' locations, near the mouth of a large river; that is, in fact, supported by the vanishingly small Shredder Index values at all sites (Table 6). A normal summer stream with strong linkage to the riparian forest generally has a Shredder Index $>0.25$ (Merritt et al. 2002).

Filtering Collector Index. (ratio: Filtering Collectors to Gathering Collectors.) This ratio is a surrogate for the relative proportion of FPOM in suspension in the water column to depositional FPOM in the benthic layer. A system with a Filtering Collector Index $>0.50$ is considered transport-FPOM enriched (Merritt et al. 2002); a large fraction of the suspended load of the system is organic rather than inorganic material, supplying a highquality resource for filter-feeding taxa and supporting a healthy, diverse invertebrate community. If FPOM has to accumulate in the benthos and be conditioned before becoming a food resource of suitable quality, Collector/Gatherers will dominate (Cummins et al. 2005). With the exception of Reach 1 in the pre-removal year, all sites are rated markedly above this threshold: sites below the dam in 2009 are particularly high in suspended organic material (Table 6). Though the river was still TFPOM enriched in 2010 , the proportion of organic material in suspension seems to have declined dramatically - perhaps as a result of increased inorganic turbidity with dam removal.

Channel Stability Index. (ratio: [Scrapers + Filtering Collectors] to [Shredders + Gathering Collectors].) The ratio of organisms that require a stable surface for attachment and/or feeding to those that inhabit more mobile substrates gives some idea of the relative permanence of the channel's bottom materials. Substrates are considered stable above a threshold of 0.50 (Merritt et al. 2002.) With the exception of Reach 1, the high Index value of the 2009 samples indicates an abundance of stable substrates (Table 6). The anomalous marginal figure for Reach 1 may result from the fact that while the collection site was a largely cobble-and-boulder-substrate, fast-moving reach, the margins in which samples were collected did show some siltation infiltrated among the cobbles; that description, as such, applies to the other sites as well, however. Though still high, the lower Index figures below the Dam in 2010 may indicate a greater level of siltation generated by the dam removal process.

Predator-Prey Index. (ratio: Predators to [Total of All Other Groups].) In most stable systems, Predators comprise about 15 per cent of the macroinvertebrate population: a greater abundance of predators indicates a high-turnover, fast-breeding prey population, possibly rebounding from an earlier disturbance and in the early stages of faunal succession (Merritt et al. 1996). A significantly lower proportion of predators, who as specialized feeders are more sensitive than generalists like the filter-feeders, is indicative of a disturbed system (Uwadiae 2010). The low Predator-Prey Index scores for all these 
sites places them in the latter category (Table 6). In 2009 all sites had index scores of 0.03-0.04; during dam removal in 2010 they had decreased to 0.01-0.02, a decrease of $50-75 \%$, perhaps indicating a significant increase in an already high disturbance level.

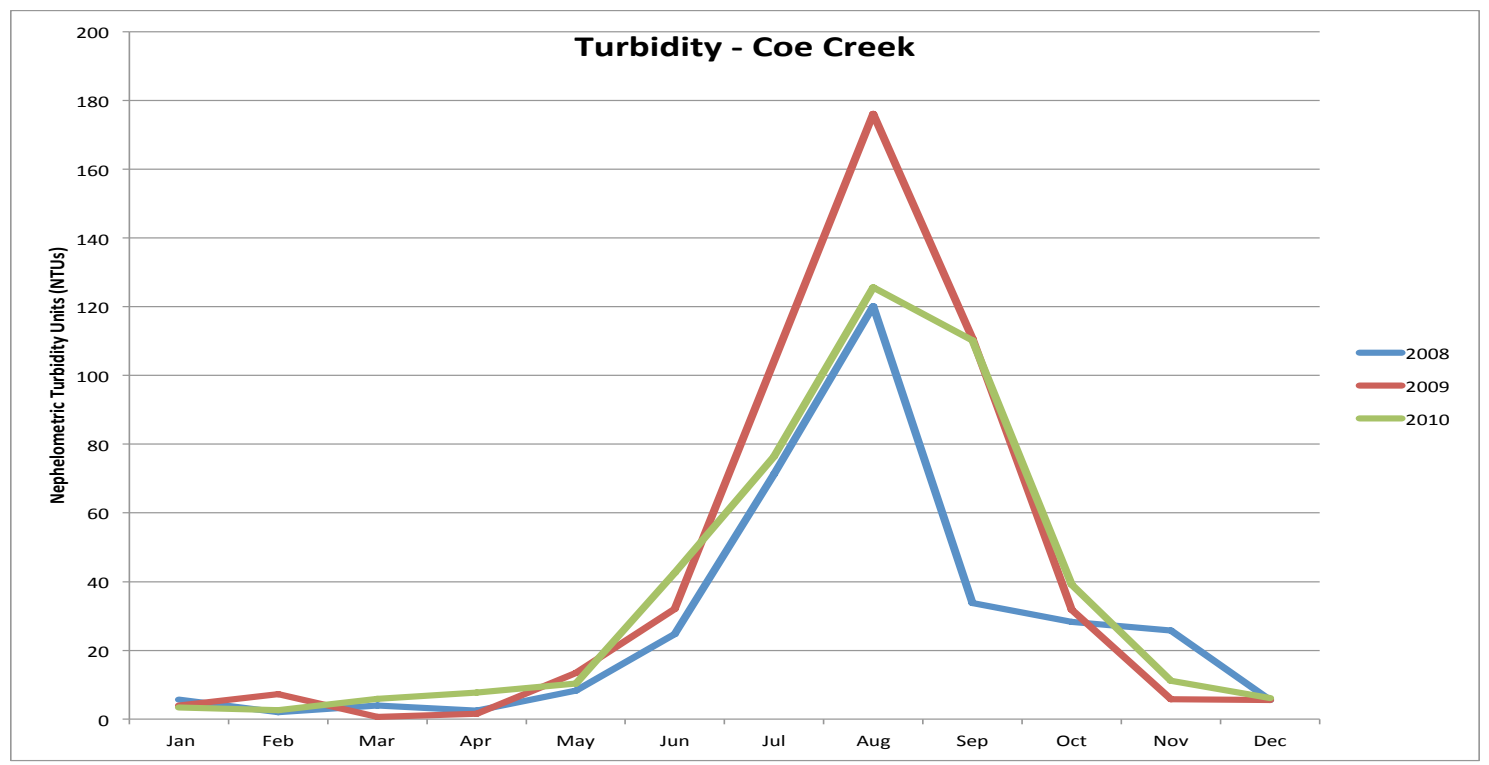

Figure 14. Annual turbidity measurements from Coe Creek irrigation diversion structure, approximately 18 miles upstream of Powerdale diversion dam, for 2008 (blue), 2009 (red), and 2010 (green). Monthly means derived from nephelometer readings taken at approximately 6 minute intervals. No readings were taken in July of 2009.

\section{Conclusions}

A wide range of analytical techniques indicates that the lower Hood River system shows some biological impairment, and that this impairment increases from upstream to downstream. The data also indicate that biological condition worsened substantially in 2010 during the removal of Powerdale Dam, increasingly so downstream.

Percentage of the three EPT orders was high in all sampling sites; the percentages were lower during dam removal in 2010, and declined significantly in the downstream sites (Figure 3). The multi-metric Benthic Index of Biotic Integrity (B-IBI) rates all sites as "slightly impaired" in 2009 (at the very low end of that cohort), and as "moderately impaired" in 2010 (except the most upstream site, which was on the "slightly impaired" threshold); the downstream sites scored progressively lower in 2010, with the most downstream approaching the "severely impaired" threshold (Tables 1, 2, \& 3). The multivariate Predictive Assessment Tool for Oregon (PREDATOR) rated all 2009 sites but one as "most disturbed" (the exception was at the low threshold of "moderately disturbed"); all 2010 sites, during dam removal, were "most disturbed", with all but one rated substantially lower than the previous year (Tables $4 \& 5$ ). Number of sensitive taxa decreased from a mean of 1.75 in 2009 to a mean of 0.75 in 2010 (Figure 5). Predator- 
Prey ratios were very low in 2009, suggesting a disturbed system; in 2010, during dam removal, they were even lower (Table 6).

The initial expectation was that the "control" site, Reach 1, was located sufficiently far upstream to isolate it from the disturbances of the dam removal process. The fact that its quality did decline according to so many measures (B-IBI, PREDATOR, tolerant taxa, sensitive taxa) appears to indicate either that the entire study site was impacted by other upstream phenomena in 2010, or that the "control" site was not in fact immune from the disturbance effects of the massive (de-)construction zone. The primary contractor of the decommissioning project asserts that neither borrow pits nor concrete disposal areas were excavated upstream of the dam, in accordance with FERC guidelines (Nick Weekly, personal communication, 2011; FERC 2005), so construction impacts do not appear to be responsible for the decline in biotic integrity of the upstream control site in 2010 .

No single factor was clearly isolated as the primary cause of systemic biological degradation; multiple factors appear to contribute to the river's overall impairment. Pesticides have been detected in Hood River and its tributaries, and the presence of those pesticides in the river has been shown to reduce macroinvertebrate abundance and diversity (Foster 2010, ODEQ 2003). The entire reach under study has been listed on the ODEQ's 1998 303(d) list for temperatures exceeding state water quality standards (ODEQ 2003), though analysis of macroinvertebrate temperature optima did not indicate an important role for elevated temperature (Figures 9-12).

Hood River is a naturally more turbid system than most Oregon rivers, due to its glacial origins (ODEQ 2010); high turbidity has been shown to impair macroinvertebrate abundance and diversity (Shaw and Richardson 2001), and is probably responsible for the dearth of resident fish populations in the basin, as well as the reluctance of salmonids to occupy the uppermost, glacial reaches (ODEQ 2010). However, turbidity data from Coe Creek, a tributary of Hood River, shows no elevation in turbidity in 2010 relative to the previous two years (Figure 14); the cause of systemic biotic degradation in 2010, including the "control" reach, would not, then, appear to be higher turbidity input from upstream. Organic pollution, though Hilsenhoff Biotic Index indicated a steady decrease in the downstream direction both years, did increase significantly at all sites in 2010 along with biological impairment (Figure 6). Again, since this pollutant increase occurred at the "control" site as well as downstream sites, the source may be more related to upstream effects of agriculture, streamflow, and precipitation than the release of impounded nutrients during dam removal.

Some biological evidence does indicate an increase in sedimentation downstream of the dam removal project, accompanying the deterioration of biotic integrity, during dam removal in 2010. Percentages of sediment-tolerant taxa increased substantially in the downstream reaches relative to the previous year (Figure 4). Number of sedimentsensitive taxa per site decreased from a mean of 2.0 in 2009 to a mean of 1.25 in 2010 (Figure 5). Channel Stability Index shows a substantial increase in mobile substrates in 2010 in all three downstream sites (Table 6). Comparisons of the sedimentation optima of missing versus replacement taxa (according to the PREDATOR predictive model) 
yielded inconclusive results (Figures 9-12). If these small changes in sedimentation are insufficient to explain the degree of impairment during the 2010 dam removal, a role may possibly be played by the release of pesticides or other pollutants from the dam impoundment. If so, as the coffer dams were still in place at the time of 2010 sampling, that pollutant release effect may be even more profound in future years as the sediment impounded by the dam is transported downstream by the now unimpeded flow of the river.

Building upon the foundation of these baseline data, future sampling and analysis, if performed regularly, will be able to establish the degree and the rate of recovery of these riverine habitats. Though ecologically impaired as a result of the dam removal process, and though their condition may continue to deteriorate with the downstream transport of impounded sediment, with the passage of time these habitats can be expected to improve in quality to pre-removal conditions and perhaps, eventually, to a more pristine state of biological integrity than that of the dammed system. As the upper Sandy River Basin is now being graced with crowds of vigorously spawning coho two short years after the removal of Marmot Dam (personal observation, Still Creek, 2010), perhaps the Hood River basin will soon teem with spawning guchinook now that Powerdale Dam no longer stands in their way.

\section{Acknowledgements}

This project was aided profoundly by the cooperation, resources, and advice of many generous experts. I would like to thank my community partner Steve Stampfli (Hood River Watershed Group) for his interest in pursuing this project, Steve Hanson (ODEQ) for the loan of equipment and solvents, Kevin Masterson (ODEQ) for important documents, and Scott Gall (West Multnomah Soil and Water Conservation District) for GPS equipment (and a job). Todd Olson and Deanna Adams of PacifiCorp smoothed my access permission issues, and Randy Labbe allowed me access to Powerdale through his property. Chris Brun, Jim Gidley, and Albert Santos of The Confederated Tribes of the Warm Springs Reservation Fish Hatchery were kind enough to let me stay at the hatchery bunkhouse while in the field. Craig DeHart (Middle Fork Irrigation District) shared Coe Creek turbidity data, thanks to Barbara Burkholder (GeoEngineers, Inc.). Ian Waite (USGS) and Rick Hafele (ODEQ) were my mentors in the study and identification of macroinvertebrates: I hope to someday possess the merest shadow of their entomological and ecological wisdom and understanding. Patrick Edwards (PSU) was very helpful with his time, suggestions, and loans of specimens and literature. Without Mike Cole's entomological expertise (ABR, Inc.), I would still be staring at bug fragments in my stereo microscope. Shannon Hubler (ODEQ) and Celeste Mazzacano (Xerces Society for Invertebrate Conservation) have my undying gratitude for their astounding generosity and patience in guiding me through the complexities of the PREDATOR software; Chuck Hawkins (Western Center for Monitoring and Assessment of Freshwater Ecosystems, Utah State University) also helped guide me through some crucial minutia. My graduate advisor in the Masters of Environmental Management program at Portland State University, Joe Maser, pointed me at Powerdale Dam and its imminent demise as a fitting arena for my interest in macroinvertebrate biomonitoring and river restoration. 


\section{References}

Ahearn, Dylan S., and Dahlgren, Randy A. 2005. Sediment and Nutrient Dynamics following a low-head dam removal at Murphy Creek, California. Limnology and Oceanography. 50(6): 1752-1762.

Andrade, Priscila C.N. 2006. The use of benthic macroinvertebrate functional feeding groups to assess stream ecosystem attributes. MS thesis. Loyola University of Chicago, Chicago, IL

Catalano, M. J., Bozek, M. A., and Pellett, T. D. 2007. Effects of dam removal on fish assemblage structure and spatial distributions in the Baraboo River, Wisconsin. North American Journal of Fisheries Management, 27(2): 519-30.

Cummins, Kenneth W., Merritt, Richard W., and Andrade, Priscila C.N. 2005. The use of invertebrate functional groups to characterize ecosystem attributes in selected streams and rivers in south Brazil. Studies on Neotropical Fauna and Environment, 40(1): 69-89.

Cummins, Kenneth W., Wilzbach, Margaret A., Gates, Donna M., Perry, Joy B., and Taliaferro, W. Bruce 1989. Shredders and Riparian Vegetation. BioScience 39(1): 24-30.

Doyle, Martin W., Stanley, Elizabeth H., Orr, Cailin H., Selle, Andrew R., Sethi, Suresh A., and Harbor, Jon M. 2005. Stream ecosystem response to small dam removal: Lessons learned from the Heartland. Geomorphology, 71: 227-244.

Federal Energy Regulatory Commission (FERC) 2005. Order amending licence, accepting surrender, and dismissing application for new license. Project No. 2659-011 and -016. 113 FERC 92,148

Flotemersch, Joseph E., Cormier, Susan M., and Autrey, Bradley C. April 2001. Logistics of Ecological Sampling on Large Rivers U.S. Environmental Protection Agency EPA/600/R-00/109

Fore, Leska A., Karr, James R., and Wisseman R.W. 1996. Assessing invertebrate responses to human activities: evaluating alternative approaches Journal of the North American Benthological Society 15 (2): 212-231.

Foster, Eugene P. 2010. Lecture: Pesticides in the Hood River Basin. Environmental Toxicology, Environmental Science and Management 520, Portland State University.

Hafele, R 2003 Oregon's Experience with Multimetric and Multivariate Approaches. National Biological Assessment and Criteria Workshop Couer d'Alene, Idaho 31 March - 4 April, 2003 
Hargett, Eric G., ZumBerge, Jeremy R., and Hawkins, Charles P. 2005. Development of a RIVPACS model for wadeable streams of Wyoming. Ecological Indicators 7 (4): 807826.

Hart, D. D., Johnson, T. E., Bushaw-Newton, K. L., Horwitz, R. J., Bednarek, A. T., Charles, D. F., Krieger, D. A., and Veluskey D.J. 2002. Dam Removal: Challenges and Opportunities for Ecological Research and River Restoration. BioScience, 52(8): 669681.

Hayslip, Gretchen, editor. 2007. Methods for the collection and analysis of benthic macroinvertebrate assemblages in wadeable streams of the Pacific Northwest. Pacific Northwest Aquatic Monitoring Partnership, Cook, Washington.

Hilsenhoff, W.L. 1987. An improved biotic index of organic stream pollution. Great Lakes Entomology 20:31

Hood River Soil and Water Conservation District (HRSWCD) 2010. Powerdale Dam Removal http://www.hoodriverswcd.org/DamRemoval.htm

Hubler, Shannon July 2008. PREDATOR: Development and use of RIVPACS-type macroinvertebrate models to assess the biotic condition of wadeable Oregon streams. Oregon Department of Environmental Quality. DEQ08-LAB-0048-TR

Hubler, Shannon and Borisenko, Aaron 2008. Hood River Pesticide Stewardship Partnership: 2008 Macroinvertebrate Summary. Oregon Department of Environmental Quality: from Kevin Masterson (ODEQ Agency Toxics Coordinator).

Huff D.D., S. Hubler, Y. Pan, and D. Drake. 2006. Detecting Shifts in Macroinvertebrate Community Requirements: Implicating Causes of Impairment in Streams. Oregon Department of Environmental Quality. Ygyg5DEQ06-LAB-0068-TR

Karr, J.R. 1981. Assessment of biotic integrity using fish communities. Fisheries 6: 21-7

Meridian Environmental, Inc. 2003. Powerdale Hydroelectric Project Biological Evaluation Prepared for PacifiCorp

Merritt, Richard W., Cummins, Kenneth W., and Berg, Martin B. 2008. Ecology and Distribution of Aquatic Insects. An Introduction to the Aquatic Insects of North America, Merritt Cummins and Berg Eds. Kendall/Hunt Publishing Company, Dubuque IA, 2008

Merritt, Richard. W., Cummins, Kenneth W., Berg, Martin B., Novak, John A., Higgings, Michael J., Wessell, Kelly J., and Lessard, Joanna L. 2002. Development and application of a macroinvertebrate functional-group approach in the bioassessment of remnant river oxbows in southwest Florida. Journal of the North American Benthological Society 21(2): 290-310 
Merritt, Richard W., Wallace, J.R. Higgins, M.J., Alexander, M.K., Berg, M.B., Morgan, W.T., Cummins, K.W., and Vandeneeden, B. 1996. Procedures for the functional analysis of invertebrate communities of the Kissimmee River-Floodplain ecosystem. Florida Scientist 59(4): 216-274

Oregon Department of Environmental Quality (ODEQ) 1995. Oregon Water Quality Index Report for Deschutes and Hood Basins, Water Years 1986-1995. STORET \#404710 http://www.deq.state.or.us/lab/wqm/wqindex/deshood3.htm

Oregon Department of Environmental Quality (ODEQ) 2003. Oregon's 2002 Section 305(b) Report January 2003

Oregon Department of Environmental Quality (ODEQ) 2008. Oregon Water Quality Index Summary Report: Water Years 1998-2007. DEQ09-LAB-008

Oregon Department of Environmental Quality (ODEQ) 2009. Water Monitoring and Assessment Mode of Operations Manual DEQ03-LAB-0036-SOP

Oregon Department of Environmental Quality (ODEQ) 2010. Changes to the Turbidity Rule Since October. www.deq.state.or.us/wq/standards/docs/turbidity/ChangesTurb Criteria1030.pdf

Oregon Plan for Salmon and Watersheds 1999. Water Quality Monitoring: Technical Guidebook July 1999

PacifiCorp 2007. PacifiCorp Powerdale Hydroelectric Project FERC No. 2659 Hood River, OR. November 2006 Flood Response Project Final Report. Prepared for the Federal Energy Regulatory Commission June 21, 2007

Poff, N. Leroy and Hart, David D. 2002. How Dams Vary and Why it Matters to the Emerging Science of Dam Removal. BioScience, 52(8): 659-668.

Roni, P., Hanson, K., and Beechie, T. 2008. Global Review of the Physical and Biological Effectiveness of Stream Habitat Rehabilitation Techniques. North American Journal of Fisheries Management, 28(3), 856-90.

Rosenberg, David M., and Resh, Vincent H. 1993. Freshwater biomonitoring and benthic macroinvertbrates. Chapman and Hall, New York, 488 pp.

Rosenberg, David M., Resh, Vincent H., and King, Ryan S. 2008. Use of Aquatic Insects in Biomonitoring. An Introduction to the Aquatic Insects of North America, Merritt Cummins and Berg eds. Kendall/Hunt Publishing Company, Dubuque IA, 2008

Santucci, Victor J., Gephard, Stephen R., and Pescitelli, Stephen M. 2005. Effects of Multiple Low-Head Dams on Fish, Macroinvertebrates, Habitat, and Water Quality in the 
Fox River, Illinois North American Journal of Fisheries Management, 25: 975-992.

Shaw, E. Al and Richardson, John S. 2001. Direct and indirect effects of sediment pulse duration on stream invertebrate assemblages and rainbow trout (Oncorhyncus mykiss) growth and survival. Canadian Journal of Fishery and Aquatic Science 58:2213-2221.

Shuman, John R. 1995. Environmental considerations for assessing dam removal alternatives for river restoration. Regulated Rivers: Research \& Management 11(3-4): 249-261.

Smith, M.J., Kay, W.R., Edward, D.H.D., Papas, P.J., Richardson, K. St J., Simpson, J.C., Pinder, A.M., Cale, D.J., Horwitz, P.H.J., Davis, J.A., Yung, F.H., Norris, R.H., and Halse, S.A. 1999. AusRivAS: using macroinvertebrates to assess ecological condition of rivers in Western Australia. Freshwater Biology 41 (2): 269-282.

Stanley, Emily H. and Doyle, Martin W. 2003. Trading off: the ecological effects of dam removal. Frontiers in Ecology and Environment 1(1): 15-22.

United States Department of Agriculture 2009. Census of Agriculture 2007, volume 1, U. S. Summary and State Reports

United States Environmental Protection Agency 2003. Field Operations Manual for Non-Wadeable Rivers and Streams, section 9

Uwadiae, Roland Efe 2010. Macroinvertebrates functional feeding groups asd indices of biological assessment in a tropical aquatic ecosystem: implications for ecosystem functions. New York Science Journal 3(8)

Vannote, R.L., Minshall, G.W., Cummins, K.W., Sedell, J.R., and Cushing, C.E. 1980. The river continuum concept. Canadian Journal of Fisheries and Aquatic Science 37: 130-137.

Wallace, J.B. and J.R. Webster. 1996. The role of macroinvertebrates in stream ecosystem function. Annual Review of Entomology 41: 115-39.

Wright, John R. 1994. Development of RIVPACS in the UK and the value of the underlying data-base. Limnética, 10 (1): 15-31. 


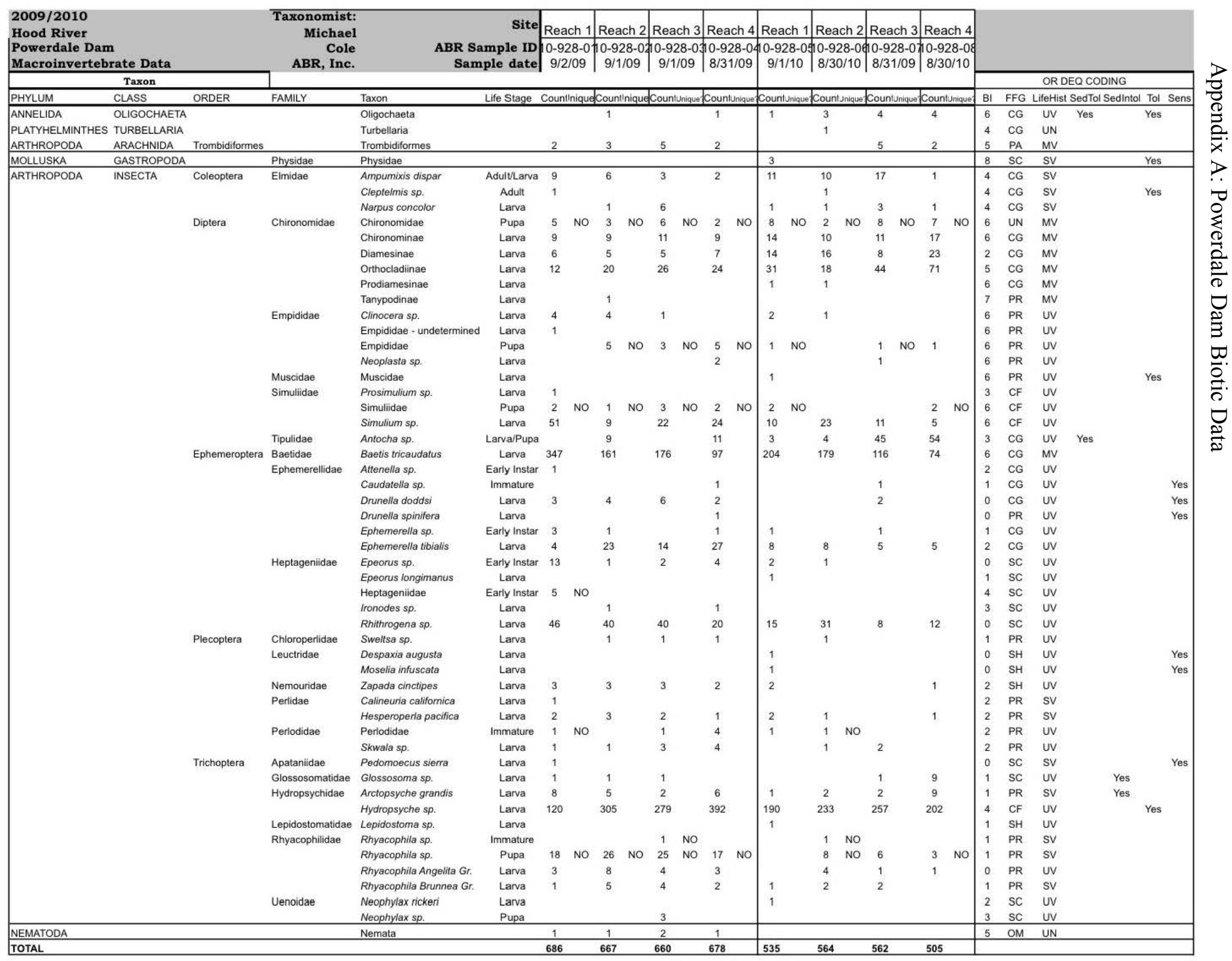

